\title{
Modelling of the Neves Corvo Area
}

\author{
C. Inverno, C. Rosa, J. Matos, J. Carvalho, \\ J.M. Castello-Branco, M.J. Batista, I. Granado, \\ J.T. Oliveira, V. Araújo, Z. Pereira, P. Represas, \\ A.R. Solá and P. Sousa
}

\begin{abstract}
3D, 4D and predictive geological modelling, including all known geoscientific data, were applied to the $100 \times 25 \mathrm{~km}$ large Neves Corvo project area located in the Portuguese part of the Iberian Pyrite Belt. The lowermost unit in the area is the Givetian to Famennian-Strunian PhylliteQuartzite Group (PQG), which is overlain by three SE-plunging volcanic axes with the Strunian to Visean Volcanic Sedimentary Complex (VSC), hosting in its lower sequence the Neves Corvo VHMS giant deposit. The VSC is covered with mid late Visean and Serpukhovian to Bashkirian flysch rocks [Mértola and Mira formations of the Baixo Alentejo Flysch Group (BAFG), respectively]. Six NE-SW deep 2D reflection seismic profiles acquired by LNEG between Neves Corvo mine and the Spanish border ( $60 \mathrm{~km}$ to the SE) during the ProMine project, allowed to extend a 3D-model of the Neves Corvo main thrust (that brings VSC rocks onto Mértola Fm. very close to VHMS ores) throughout the eastern part of the area. NE-SW to ENE-WSW (sinistral) and N-S to NNW-SSE (dextral) late Variscan strike-slip oblique faults (a few $>5 \mathrm{~km}$ deep) displaced all former geological units and structures, as shown by the $3 \mathrm{D}$ models. In late Variscan time, small vein-type $\mathrm{Cu}$ (and other metals) deposits were emplaced along them.
\end{abstract}

C. Inverno $(\bowtie) \cdot J$. Carvalho $\cdot$ M.J. Batista

I. Granado · J.T. Oliveira · P. Represas · A.R. Solá

Laboratório Nacional de Energia e Geologia

(LNEG), Estrada Portela-Zambujal, Apartado

7586, 2610-999 Alfragide, Portugal

e-mail: carlos.inverno@lneg.pt

C. Rosa

Empresa de Desenvolvimento Mineiro SA (EDM), Rua Sampaio e Pina 13 DTO, 1070-248 Lisboa, Portugal

J. Matos · P. Sousa

LNEG, Rua Frei Amador Arrais, 39 r/c, Apartado

104, 7801-902 Beja, Portugal
J.M. Castello-Branco

Geology and Geotechnics Consultores Lda., Rua

Cunha Júnior, 41b Sala 1.6, 4250-186 Porto,

Portugal

V. Araújo

Rua Sub-carreira, 575, 4815-517 Vizela, Portugal

Z. Pereira

LNEG, Rua da Amieira, Apartado 1089, 4466-901

S. Mamede Infesta, Portugal 
The 4D model enabled to establish a clear age sequence of mineralization types, inferring also that VHMS mineralization may possibly exist at depth between the Neves Corvo mine and the Alcoutim sector (near the Spanish border). The 3D predictive model, constructed exclusively for the restricted area of the Neves Corvo mine, pinpoints, both through the 3D-density (from gravity inversion) and the \% Cu-drill hole-based block diagrams, not only the known Neves Corvo orebodies, but also other possible extensions. The regional extension of the Neves Corvo model increases significantly the overall exploration potential of the whole IPB region in this study.

\subsection{Introduction}

In the geographic area covered by this project four main antiformal structures encompassing the Iberian Pyrite Belt succession are recognized: Castro Verde-Casével, Neves Corvo-Rosário, Ourique and Alcoutim (Fig. 11.1). In all these antiforms the rock exposure is largely dominated by the Volcanic Sedimentary Complex (VSC) lithologies and the underlying Phyllite-
Quartzite Group (PQG) is only exposed in the Lançadoiras region, $1 \mathrm{~km} \mathrm{NW}$ of Neves Corvo mine. The Pyrite Belt succession is stratigraphically overlain by the Mértola Formation (Fm) turbidites of the Baixo Alentejo Flysch Group but tectonic imbrications among this formation and the other Pyrite Belt lithostratigraphic units may occur. Distinct turbidites of the same flysch group make up the Mira Fm that covers Mértola Fm rocks at the southeasternmost end of the project area.

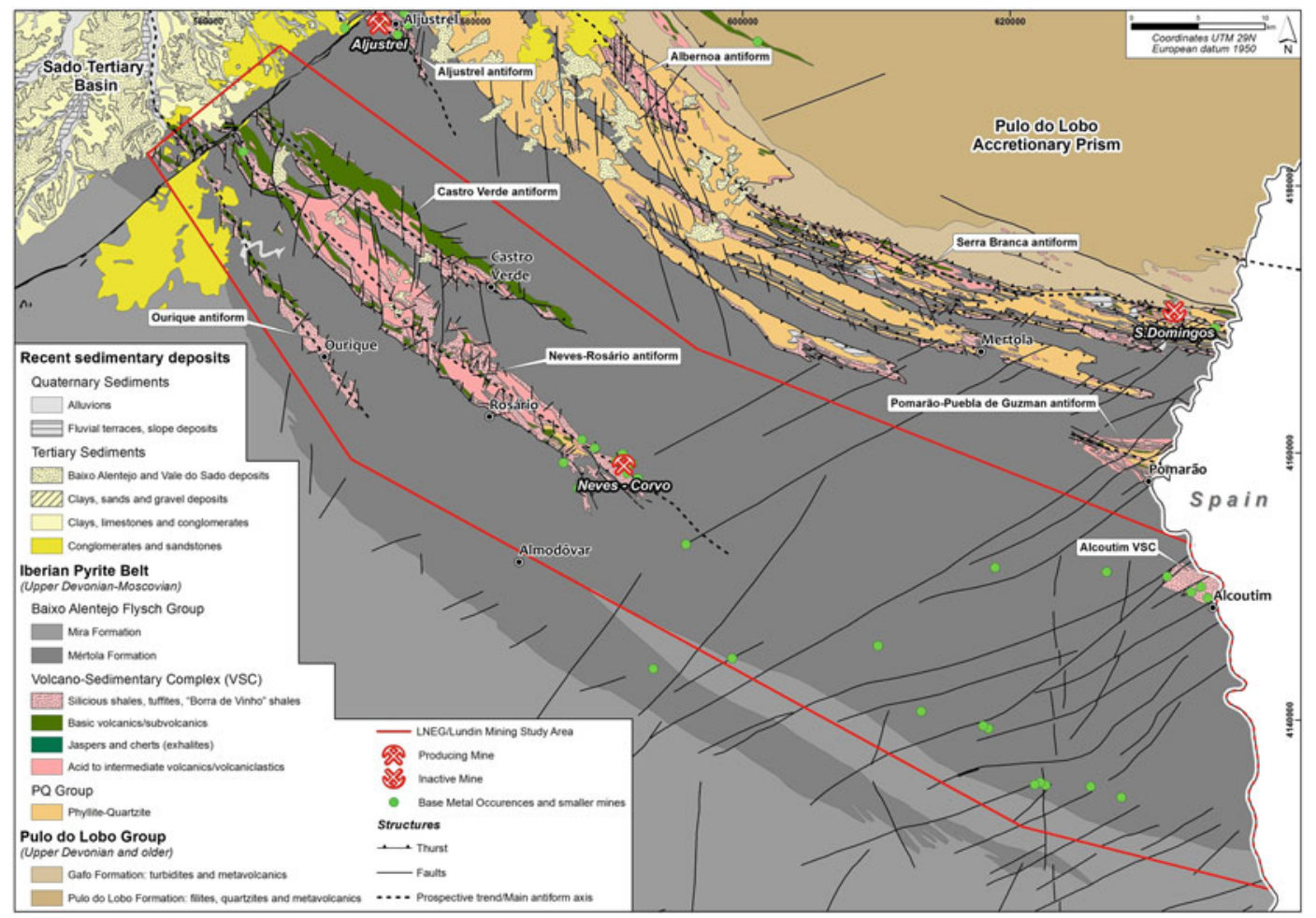

Fig. 11.1 Regional geology map of the Neves Corvo project area (modified from Lundin Mining 2012) 
The existing geological knowledge of these antiforms is very different from one another: while the Neves Corvo mine area at the SE termination of the Neves Corvo-Rosário antiform has been studied in detail, the knowledge of the remaining areas is still limited. As such, we will briefly describe the geology of these remaining areas of the antiforms and will later describe the Neves Corvo mine region.

The stratigraphy of all the antiforms is composed of three main groups of lithologies, all belonging to the VSC: felsic volcanic rocks $(\mathrm{V} \alpha)$, mafic volcanic rocks $(\mathrm{V} \beta)$ and dark shales and fine volcanogenic sedimentary rocks (XV) in which the volcanic rocks are interbedded.

The felsic volcanic rocks are dominant in the Neves Corvo-Rosário antiform where they form the outcropping core of this tectonic structure. Rhyolites, rhyodacites and felsic volcaniclastics represent the dominant rock types. The same types of volcanic rocks occur in the Castro Verde - Casével antiform but are absent in the Ourique antiform.

The mafic volcanic rocks comprise mostly basalts and dolerites and tend to occupy a stratigraphic position high in the VSC succession. Pillow lavas and hyaloclastites are common. Rare limestone lenses at the top of these volcanics contain conodonts of late Visean age (Oliveira 1983).

The XV lithologies comprise dark and black shales, thin-bedded siltstones, siliceous shales and fine volcanogenic sediments and purple shales. Siliceous, manganese oxides, phosphate and siderite nodules can be found dispersed in all these shales. The XV lithotypes are dominant in the Alcoutim antiform and represent an important proportion in the Ourique antiform.

The Mértola Formation consists of classic turbidites characterized by packages of greywacke beds of variable thickness and grain size alternating with bands of shales and siltstones. The greywacke beds show the typical sedimentary structures that are common in deep water gravity clastic sedimentation (turbidites s. 1.). The thickness given by exposed sections and drill cores is variable, depending on the tectonic blocks, and may reach 1500 m. Fossils of Posidonia becheri, ammonoids and palynomorphs indicate a late Visean age
(Oliveira 1983; Korn 1997; Oliveira et al. 2004). This unit outcrops in about $70 \%$ of the project area and the investigation of the sector situated between the Neves Corvo mine and the Portuguese/Spanish border is one of the main goals in the present project. The Mira Fm, outcropping in the vicinity of the border, is $1000-2500 \mathrm{~m}$ thick and made up of fine-grained greywackes, siltstones and shales of Serpukhovian age (several species of the Order Goniatitida; Oliveira and Wagner-Genthis 1983).

All the stratigraphic units are affected by NWtrending folds and associated cleavage dipping $60-70^{\circ}$ towards NE. Folds styles vary from isoclinal in the VSC and PQG units to asymmetrical folds with long normal limbs and short reverse limbs in the Mértola and Mira formations and all show vergence towards SW. The VSC may exhibit an earlier cleavage, also NW-trending, not as penetrative as the main cleavage. Thrust faults parallel to the main cleavage may occur, a few extending continuously throughout the project area, as well as late near-vertical faults grouped in two main families, NW-SE, dextral and NE-SW, sinistral.

Metamorphism in the Pyrite Belt units is syn- to late-orogenic and characterized by the prehnitepumpellyite-lower greenschist facies (Munhá 1983a, b). The volcanic rocks and the rocks hosting the massive sulphides ores are also affected by a pre-orogenic hydrothermal metamorphism underlined by the development of calcite, sericite and chlorite (Munhá 1990). The Mértola and Mira formations turbidites are metamorphosed in the prehnite-pumpellyite/zeolite and zeolite facies, respectively (Munhá 1983a).

Mapping carried out in the larger Neves Corvo mine region (Leca et al. 1983) complemented by logging of dozens of drill cores by mine geologists, palynostratigraphic research (Oliveira et al. 1997; Pereira et al. 2003; Oliveira et al. 2004) and recent research on the SE part of the Neves Corvo-Rosário antiform (Rosa et al 2008; Oliveira et al. 2013) identified the regional stratigraphic sequence described below.

The Phyllite-Quartzite Group is represented by the dark shales with siliceous lenses and nodules of the Barrancão member, which are overlain by shales, siltstones and quartz- 
sandstones of the Phyllite-Quartzite Formation. The unit's thickness as a whole is in excess of $100 \mathrm{~m}$ (base not seen). Palynomorphs indicate a late Famennian age for the Barrancão member and a Strunian (latest Famennian) age for the PhylliteQuartzite Fm (Oliveira et al. 2004, 2006, 2013; Pereira et al. 2008). At the Monte Forno da Cal farm and at depth, the top of the Phyllite-Quartzite Group is overlain by a tens of meters thick shale band with interbedded limestone lenses and nodules. The latter yielded conodonts of upper Famennian age (Boogaard and Schermerhorn 1981).

The VSC has been divided into two main sequences that appear separated by a stratigraphic gap marked by the absence of Tournaisian sedimentary rocks (Oliveira et al. 2004). The Lower VSC sequence is composed of rhyolites, rhyodacites, volcaniclastic sedimentary rocks, basalts and dolerite sills. Its thickness varies depending on the distribution of the volcanic facies and may reach $500 \mathrm{~m}$. Shales interbedded in these volcanic rocks yielded palynomorphs of Strunian age (Oliveira et al 2004; Pereira et al. 2008). The massive sulphides occur at the top of the felsic volcanic rocks usually associated with black shales. Deep in the mine area, this lower sequence is unconformably overlain by greywackes and shales of the Mértola Fm (Mt2) which thickness is variable, from a few meters to several tens of meters, depending on the sea floor paleotopography. Fossils of ammonoids and palynomorphs show that these turbidites are of upper Visean age (Oliveira et al. 2004; Pereira et al. 2008). The time gap between these turbidites and the underlying VSC rocks has been related to submarine erosion that removed the Tournaisian sediments (palynomorph reworked assemblages are found in the overlying younger units; Oliveira et al. 2004).

The Upper VSC sequence is composed of the Grandaços Fm (dark shales with phosphate nodules, cherts and fine volcanogenic sedimentary rocks), "Borra de Vinho" purple shales Fm and Godinho Fm (shales, siliceous shales and felsic volcaniclastic rocks), $300 \mathrm{~m}$ thick altogether. In the Neves Corvo mine, this lithostratigraphic succession has been dated as lower upper Visean, based on palynomorphs (Oliveira et al. 2004). At depth in the mine area, drill cores have shown that gray siliceous and black shales rich in phosphate nodules (Graça Formation) occur below the Godinho Fm. This unit has locally intercalations of felsic volcanic rocks. The black shales contain palynomorphs of lower Visean age (Oliveira et al. 2004). The recently mapped$150 \mathrm{~m}$ thick-Ribeira de Cobres Fm (Oliveira et al. 2013), with shales, siltstones and fine volcaniclastic rocks, may represent a lateral facies variation of the Graça Fm. Above the Godinho Fm dark shales and thin-bedded greywackes of the Brancanes Formation that make the transition to the Mértola Fm flysch turbidites (Mt1) occur. Both units have an upper Visean age given by palynomorphs and ammonoids (Oliveira et al. 2004).

The thrust of Upper VSC/Mt2 flysch rocks is particularly relevant as a tectonic marker at the Neves Corvo mine site, since it is very close to massive sulphide ore and serves in the area as a guide to Neves Corvo VHMS ore position.

Recent U-Pb dating of zircons recovered from felsic rocks in the SE region of the Neves CorvoRosario antiform indicated five episodes of felsic volcanism at 384, 373, 365, 359 and $354 \mathrm{Ma}$ respectively (Oliveira et al. 2013). This indicates that a high heat flow was operative for $30 \mathrm{Ma}$ and may have had an important role in the formation of convective cells that lead to the genesis of the massive sulphides.

Correlations from drill cores in the mine area show that mostly the Upper VSC sequence, but in many places the Lower VSC sequence as well, is stacked in tectonic sheets that were transported over the lower Mértola Fm turbidites (Mt2) (Fig. 4 in Oliveira et al. 2004) during the Variscan orogeny. This structural arrangement proved to be of fundamental importance for the interpretation of the deep seismic profiles that were performed in this project between the Neves Corvo mine and the Spanish border.

\subsection{Methodology}

The modelling of the Neves Corvo project area was done using geological data from surface and exploration drill holes, and seismic, gravity, 
magnetic and electromagnetic data. This information was compiled from pre-existing data available at LNEG and from Lundin Mining, complemented with new data acquired during the PROMINE project to fill data gaps. The preexisting data were acquired by LNEG in regional surveys, and by exploration companies that had exploration licenses relative to parts of the project area. All geological and geophysical information have been compiled throughout time and homogenised at LNEG, which is an essential procedure to integrate data from different sources and therefore draw the interpretations required to model the project area. Nevertheless, and given the large geographic extent of the Neves Corvo project area, the type of information available and its detail was quite variable. Surface geological information was available for the whole region. However, geological information at depth was difficult to obtain since exploration drill holes occur in clusters (concentrated over geophysical anomalies) and have a variable distribution. Additionally, the distribution of different geophysical surveys and methods is also variable, and mainly conditioned by the surface geology, implying that the project area turned out not to be entirely surveyed by one single method. Therefore, and according to the extent and variability of the available data, the modelling of the project area was done in three phases.

The NW sector of the project area was modelled by surface geological maps, geological log analyses of relatively shallow (up to $1000 \mathrm{~m}$ ) drill holes, and TEM, gravity, magnetic and radiometric data. The modelling of the central part of the area, that concerns Neves Corvo mine and surroundings, was based on geological logs from deep (up to $1900 \mathrm{~m}$ ) drill holes, surface and underground geology from the mine, combined with detailed seismic, gravity and TEM data. The SE sector (including Alcoutim) of the project area was mainly modelled by seismic data acquired under the Promine project, combined with TEM data and geological logs from few relatively deep (up to $1300 \mathrm{~m}$ ) drill holes. The integration of the wide, variable and extensive information available was made using gOcad and GIS software. The models for the near Neves
Corvo mine area were produced by Lundin Mining that currently exploits the massive sulphide deposits of Neves Corvo and were included in gOcad as well. The scarcity of geological and geophysical data for the area between Neves Corvo mine and Alcoutim (SE sector of the project area) and the great depth of the top of the VSC complex were the motivation to conduct a seismic reflection survey in this area. Seismic reflection data are an essential tool to obtain structural and physical properties information of the subsurface at great depth. It has long been employed to study tectonic and sedimentary evolution of sedimentary basins, where impedance contrast is generally strong enough to allow imaging of the subsurface based on reflections. In the last decades, due to the advances in electronics such as 24 bit A/D converters and processing techniques, the seismic reflection method has gained a dramatic increase in the number of applications to hard-rock exploration (e.g. Kim et al. 1994; Radzevicius and Pavlis 1999; Eaton 2003). The mining industry is one of the fields where the seismic reflection method has shown great utility to complement the more generally applied gravimetric, magnetic, electrical and electromagnetic methods in VSC.

Metallic ore deposits such as the VHMS deposits of the IPB are commonly associated with high-angle structures, strong deformation and metamorphism, which prevented in past the use of seismic methods to locate them. Recent developments in migration algorithms and the surge of new methods which increased coverage and signal to noise ratio in poor reflectivity areas, such as the common reflection surface (CRS) method or 3D seismics (e.g. Hubral 1999; Cordsen et al. 2000), have changed the scenario. The seismic reflection method has now the capability of providing important structural information that coupled with the potential methods used in mineral exploration can become an important asset. Both 3D and 2D seismic methods have provided successful case histories in the mining industry. In the Portuguese mainland, the first seismic reflection profiles acquired for this purpose in Alentejo by Compagnie Générale de Géophysique (CGG) were supported 
by Somincor in 1991 and 1996. The results were not conclusive and they were soon forgotten. Not much after the last CGG survey, the first deep seismic reflection profile started in the Spanish part of the IPB, close to the Portuguese border (e.g. Simancas et al. 2003; Carbonell et al. 2004). In Portugal, useful results were obtained using seismic reflection and gravimetric modelling for shallow massive sulphides exploration, under a relatively thin Tertiary cover that occurs in the NW part of the IPB (Oliveira et al. 1998; Carvalho et al. 2011). Due to the superior resolution and depth penetration the seismic reflection method was the most suited for the purpose of geological modelling of the IPB. The mechanical soundings generally do not exceed $2-3 \mathrm{~km}$, while potential-field data give information at various wavelengths that are originated at different depths. Short wavelengths are usually attributed to shallow sources in the upper crust while long wavelength anomalies originate at greater depth. Gravimetric data has been useful to locate massive ore bodies at depths above $1 \mathrm{~km}$. Aeromagnetic data has been less useful to locate sulphide deposits since these are associated with felsic volcanic rocks (that have lower magnetic susceptibilities than mafic volcanic rocks) and due to the greater sensitivity of the magnetic field to lithological changes when compared with the gravimetric field. Electrical and electromagnetic methods often applied in the area are useful to locate ore bodies also up to 1-2 km depth, but they do not provide accurate structural information such as the location of major thrust planes and faults.

Therefore, six 2D seismic profiles striking approximately SW-NE, perpendicular to the main geological structures, and totalling $82 \mathrm{~km}$ were planned and carried out by LNEG for the Neves Corvo mine-Alcoutim sector (see Sect. 11.3.2). Due to the depth penetration required (4-5 km), the seismic equipment available at LNEG was not adequate for this purpose and it was necessary to rent equipment from a large geophysical services company. Prospectiuni company (Romania) was already working in Portugal and had wireless seismic equipment that allowed greater flexibility in data acquisition. Villages, roads, small rivers could be easily crossed and the initial design of the profiles could be followed more closely. The system used was the state of the art cable-less Sercel 428, E-Unite Full with 480 active channels, six in-line geophones per channel, a channel spacing of $25 \mathrm{~m}$ and a source interval of $50 \mathrm{~m}$, resulting in 120 full fold data. The source used was provided by three synchronised ION AHV-IV vibroseis trucks of 28.5 tons each. A linear up sweep $16 \mathrm{~s}$ long with a frequency varying between 10 to $90 \mathrm{~Hz}$ was used to allow recording information from shallow and deeper reflections. Two or three vibrations per vibration point were carried out. Finally, SG $10 \mathrm{~Hz}$ receivers were employed to record the seismic wave field, which was sampled at $2 \mathrm{~ms}$ rate during six seconds.

Several processing sequences were attempted for each profile. A standard processing sequence with Pre-Stack Time Migration (PSTM) and post-stack migration, and a second processing sequence with the common-reflection surface method (CRS; Mann et al. 1999) also coupled with PSTM and post-stack migration. All processing sequences included geometry introduction (crooked line geometry for lines 3, 4, 5 and $6)$, trace editing, first break and bottom muting, refraction statics computations (weathering zone velocity of $1 \mathrm{~km} / \mathrm{s}$ and replacement velocity of 4$5 \mathrm{~km} / \mathrm{s}$ ) and conversion to flat datum, FK filter, spherical divergence correction, spiking deconvolution (zero phase with $240 \mathrm{~ms}$ operator length), bandpass frequency filtering (8-12-70$80 \mathrm{~Hz}$ ), automatic gain control (AGC, $500 \mathrm{~ms}$ window length), two iterations of velocity analysis and residual statics calculations and, finally, the normal moveout (NMO) correction.

From this point the standard and PSTM processing sequences diverged. The CDP gathers were either stacked and post-stack F-X deconvolution and AGC applied, or/and prepared for PSTM. In the first case, Steep Dip Explicit Finite Difference Time Migration was applied to the stacked sections, while in the second the CDP gathers were prepared for PSTM. A 2D Kirchoff time migration algorithm with an aperture of 3-5 km was applied to the gathers. To conclude the processing sequence, CDP stacking and some post-stack filtering was applied. The CRS processing sequence was identical to the previous one until the 
pre-PSTM gathers and before NMO correction, after which FX-deconvolution, creation of CRS gathers and stacking were carried out. From this point onwards, the standard and PSTM sequences were applied to the CRS gathers.

Migration was essential to image appropriately these profiles due to the steep dips present. The CRS stacked sections resulted in a clear improvement of the signal to noise ratio. PSTM sections show a better coherency of the reflectors and a clear improvement in the conflicting dips affecting all profiles that resulted from the 3D nature of the geological structures but some artefacts were introduced anyhow in the stacked sections. For the final interpretation, it was an advantage to have both processing sequences and non-migrated stacks.

The seismic reflectors observed in the seismic profiles were interpreted and correlated with the geology, based on the geological information obtained from exploration drill holes located close to the profiles and also from the knowledge of the regional geology. The integration of all data sets was georeferenced and integrated in gOcad, which was a complex task, due to the distinct investigation depths. Gravimetric, aeromagnetic, radiometric and TEM data were also used to interpret each profile, to aid the study of lateral variations of VS units, locate igneous structures (e.g. several dykes associated with late Variscan faults) and the interpretation of deeper units. Information from the Iberseis profiles (Simancas et al. 2003; Carbonell et al. 2004) was used for this. When all the profiles were interpreted, we checked the consistency of the interpretation with gravimetric and aeromagnetic data that covered almost all the study area.

\subsection{D Modelling of Project Area}

\subsubsection{Area in and Around Neves Corvo Mine}

A detailed drill hole-based 3D geological model covering the total extent of Neves Corvo VHMS deposit (see Fig. 11.2) and its immediate NW and SE along strike extensions was developed by Lundin Mining within the scope of their exploration activities in the IPB Portuguese sector. Geophysical data were also used in the modelling. 2D and 3D seismic reflection profiles indicated the location of several thrusts, faults, and possible lithological contacts and in places the presence of some massive sulphide orebodies (e.g., Lombador and Semblana; Fig. 11.3). TEM and gravity data were also extensively acquired to locate the presence of VHMS deposits. Together with geological outcrop and drill hole data, the geophysical dataset provided valuable information between drill holes and, in particular, seismic data with its greater depth penetration allowed modelling up to several kilometers.

The main objective was to define exploration vectors for targeting by modelling the spatial distribution of specific "marker-horizons" of the known stratigraphic sequence in order to outline trends and favourable areas where lateral and down dip extensions of the prospective ore horizon might potentially occur.

Detailed 3D modelling was done using Gemcom software, version 6.4. The model covered an area of approximately $68 \mathrm{~km}^{2}$, on which a total of 4165 combined underground (from the Neves Corvo mine) and surface drill holes have been considered. Interpretation was made along parallel 50-250-m laterally spaced NE-SW oriented sections, where nearly 3000 drill hole intersects have been selected to model the horizons by creating best-fit surfaces. A total of three horizons were modelled, namely the lower contacts of the turbititic upper Mértola Fm., the VSC Xistos Verdes e Violetas Fm. ("Borra de Vinho" green and purple shales), as well as the top of the PQG (Figs. 11.5, 11.6 and 11.7). The Neves Corvo massive sulphide lenses, Neves, Corvo, Graça, Zambujal and Lombador, and the new Semblana orebody were integrated in the model (data from Lundin Mining/ Somincor and AGC companies). The Neves Corvo mine geological sequence (Oliveira et al. 2006; Relvas et al. 2006a; Pereira et al. 2008) was also used as the reference model applied to the project area. 


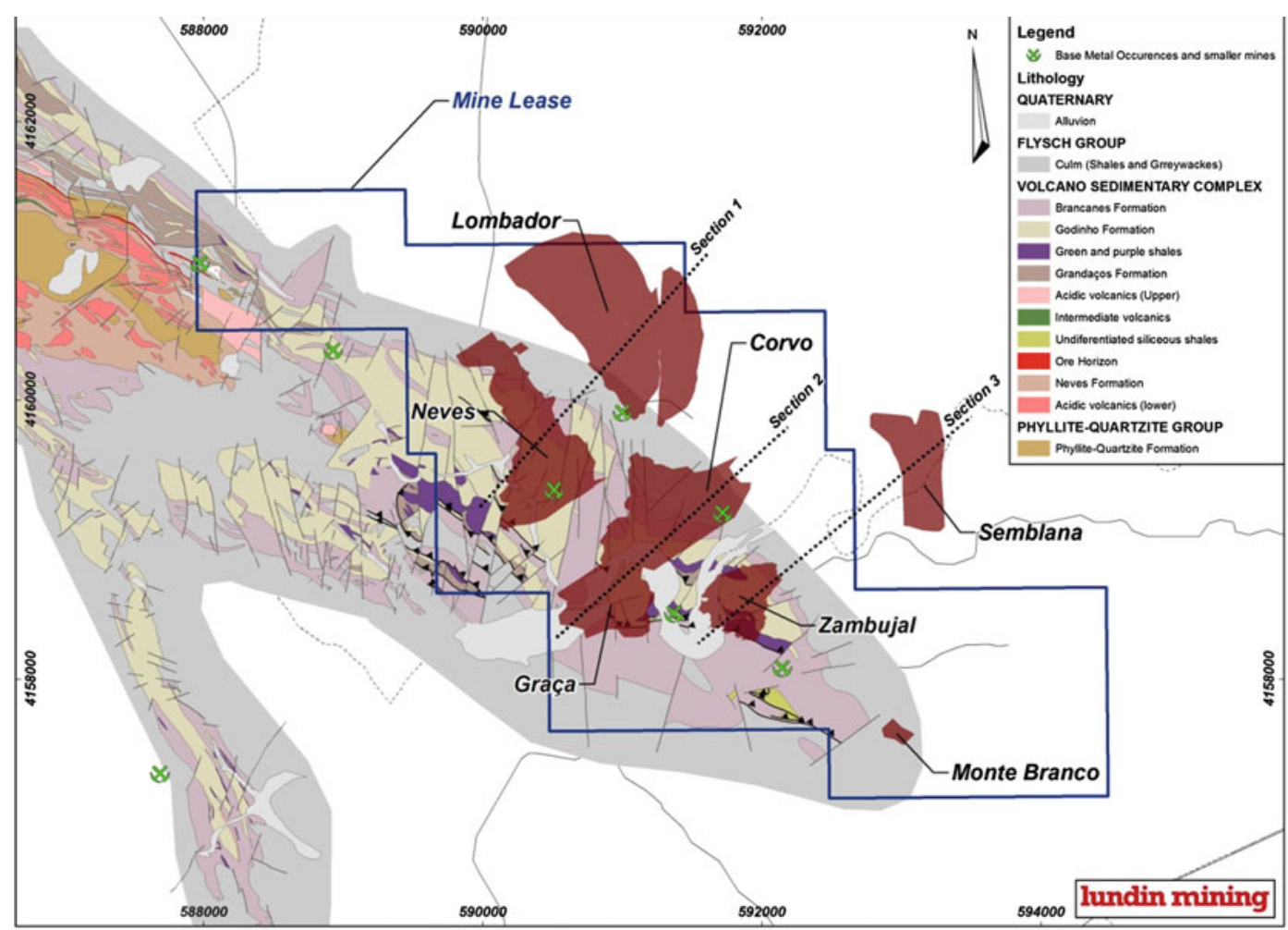

Fig. 11.2 Geological map of the Neves-Corvo antiform with the projection of vertical sections along the ore-bodies used for the geological modelling displayed (see Figs. 11.5, 11.6 and 11.7). The newly discovered Semblana and Monte Branco orebodies are also included (from Lundin Mining map 2012)
Fig. 11.3 3D seismic cube - vertical slices showing location of Semblana and Lombador reflectors with the Neves Corvo ore bodies

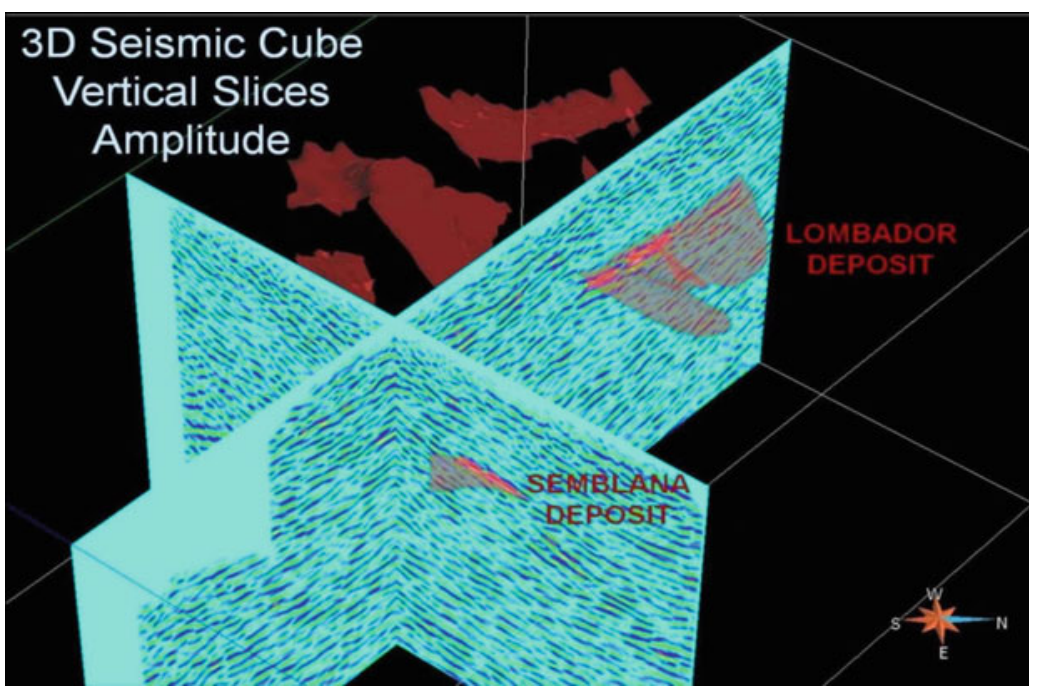




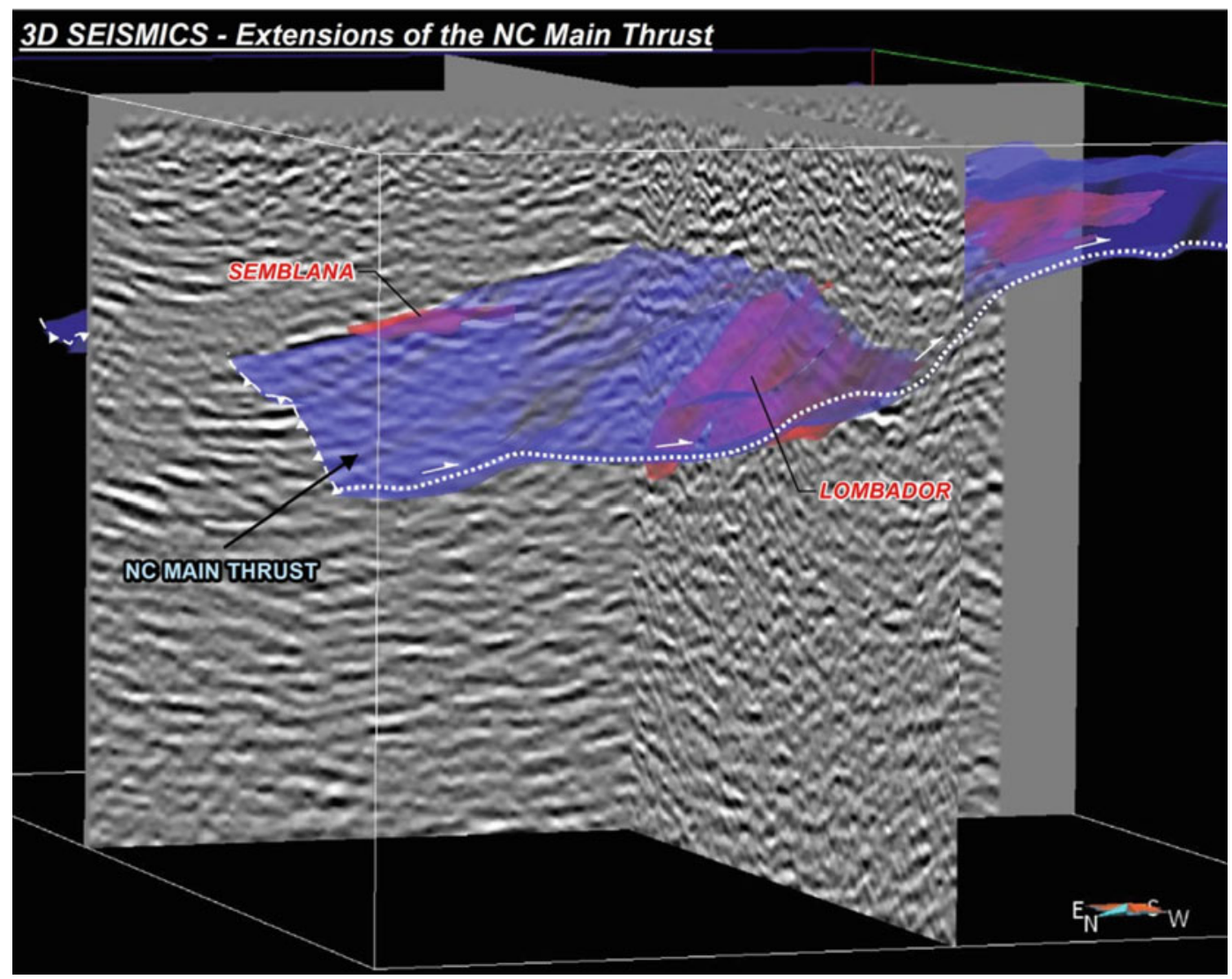

Fig. 11.4 $3 \mathrm{D}$ view of TEM sections and gravity excess mass isoshells in the Neves Corvo Mine area with the projection of the ore bodies

Based on geologic outcrop, drill hole and some geophysical (TEM, gravity and magnetics) data, LNEG extended the Lundin Mining 3D model, more centered on Neves Corvo mine and surroundings, to a zone some $7 \mathrm{~km}$ to the NW, but still within this central area of the project. The modelling of this extension was done in a more simplified way, with the exclusion of the horizon of top of the "Borra de Vinho" green and purple shales Fm. of VSC. The same horizon was not considered for the modelling of the SE and NW sectors (see Sects. 11.3.2 and 11.3.3) either.

In addition to the stratigraphic focus of the model, structural aspects were also considered by modelling the Neves Corvo Main Thrust (Figs. 11.4, 11.5, 11.6 and 11.7; Oliveira et al. 2004; Relvas et al. 2006a), a complex deformational shear corridor developed on top of the massive sulphides that splits an allochthonous block from an underlying prospective parautochthonous sequence (see Sect. 11.1). This major structural panel is interpreted as having played a key role on the mechanical/geometrical controls of the mineralization and on the concentration of the copper-rich ore shoots and therefore providing important exploration guidance on the definition of drill targets for new discoveries. It is important to emphasize that the combined use of these geological and geophysical exploration tools in the interpretation process was critical in delineation of the target area that led to the discovery of the new Semblana and Monte Branco massive sulphide deposits (Lundin Mining 2010, 2012). 


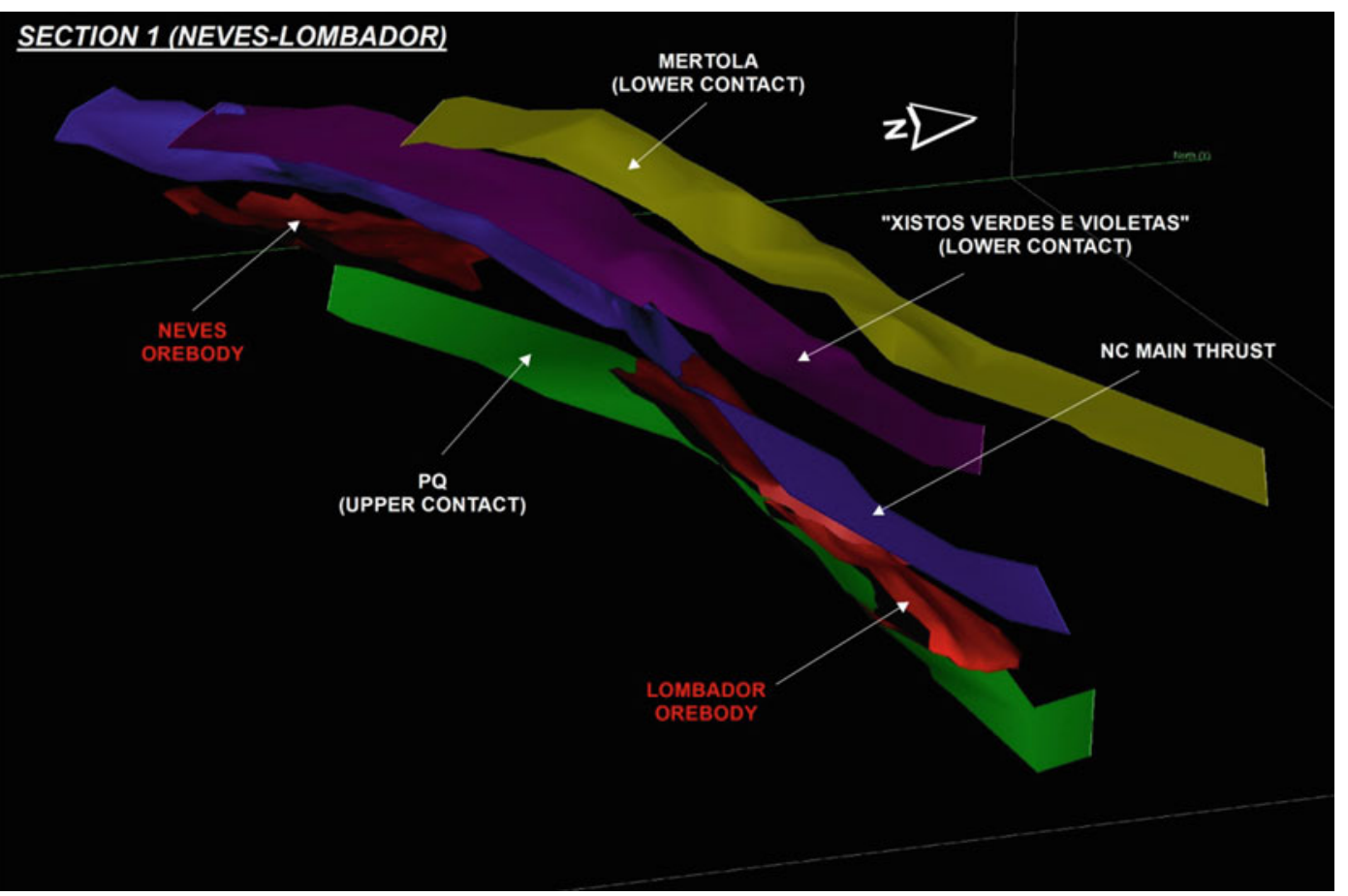

Fig. 11.5 Section-1 (see position in Fig. 11.2) along Neves-Lombador ore bodies showing the modelled surfaces using drill-hole intersections

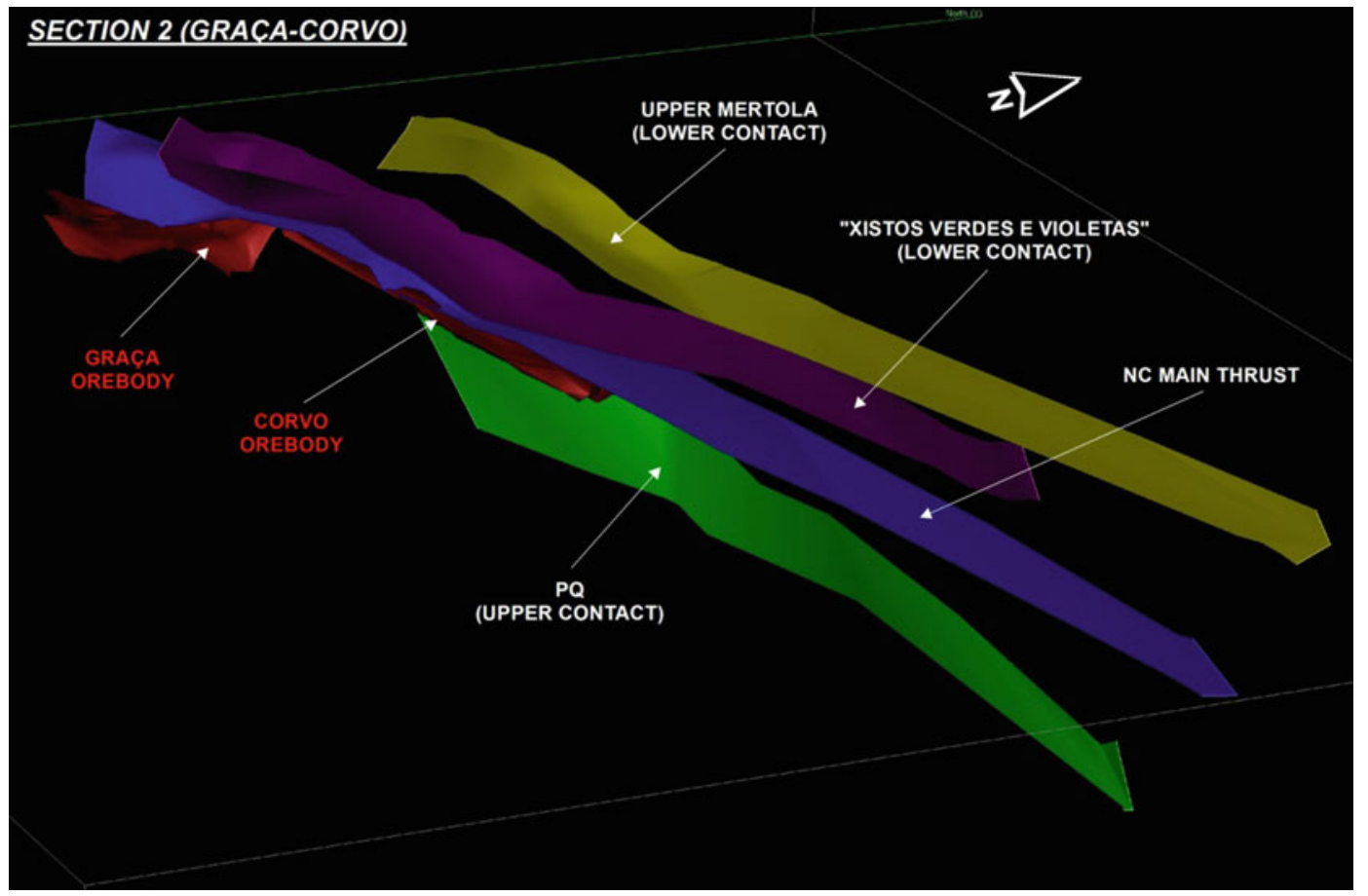

Fig. 11.6 Section-2 (see position in Fig. 11.2) along Graça-Corvo ore bodies showing the modelled surfaces using drill-hole intersections 


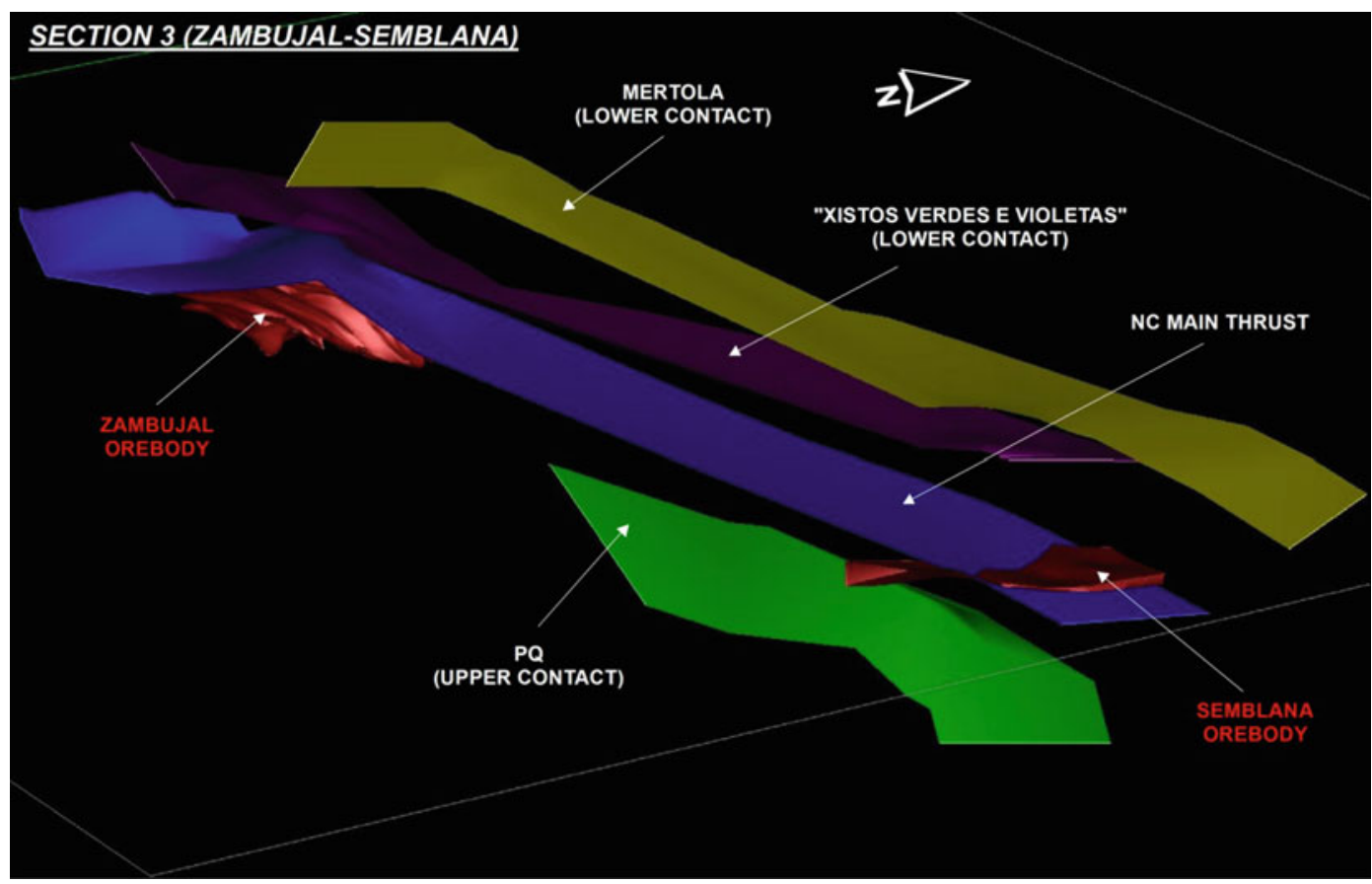

Fig. 11.7 Section-3 (see position in Fig. 11.2) along Zambujal-Semblana ore bodies showing the modelled surfaces using drill-hole intersections

\subsubsection{SE Sector (Including Alcoutim)}

In this sector the modelling was based mostly on 2D seismic reflection data acquired under the scope of the Promine project (see above). The six SW-NE seismic profiles (Fig. 11.8) were interpreted taking into consideration the information from exploration drill holes, outcrop data at various scales and other geophysical data. The latter include aeromagnetic and radiometric (natural gamma-ray) data from surveys flown at an altitude of $90 \mathrm{~m}$, gravimetric and magnetic data obtained by exploration companies, and also some TEM profiles. The gravimetric and magnetic data have been integrated and homogenised at LNEG. Additionally, seismic reflection data acquired in 1991 and 1996 by CGG for Somincor was also taken into consideration, as well as unpublished data from very recent $3 \mathrm{D}$ and $2 \mathrm{D}$ seismic reflection surveys carried out by Lundin Mining in the Neves Corvo mine area. The geological data used to model this area were compiled from LNEG published national geological maps and ongoing surveys, and from unpublished maps and cross-sections done by exploration companies, including Billinton and Lundin Mining, that have worked in the area. All data were georeferenced and integrated in gOcad.

The seismic reflection survey penetrated to a greater depth than any of the geophysical potential field methods or mechanical soundings. In the profiles closer to the Neves Corvo mine (profiles 1 and 2), clear reflections were obtained from depths up to 4 to $5 \mathrm{~km}$, while in the profiles located further SE (profiles 3, 4, 5 and 6) information was obtained from up to $10 \mathrm{~km}$ depth. After processing, it became evident that a good part of the stronger reflectivity patterns detected in each stacked section has a structural imprint that is stronger than the more subtle reflectivity variation of the lithological changes.

It was concluded that the extension of the Neves Corvo volcanic axis below the flysch sedimentary rocks, known from former drill 


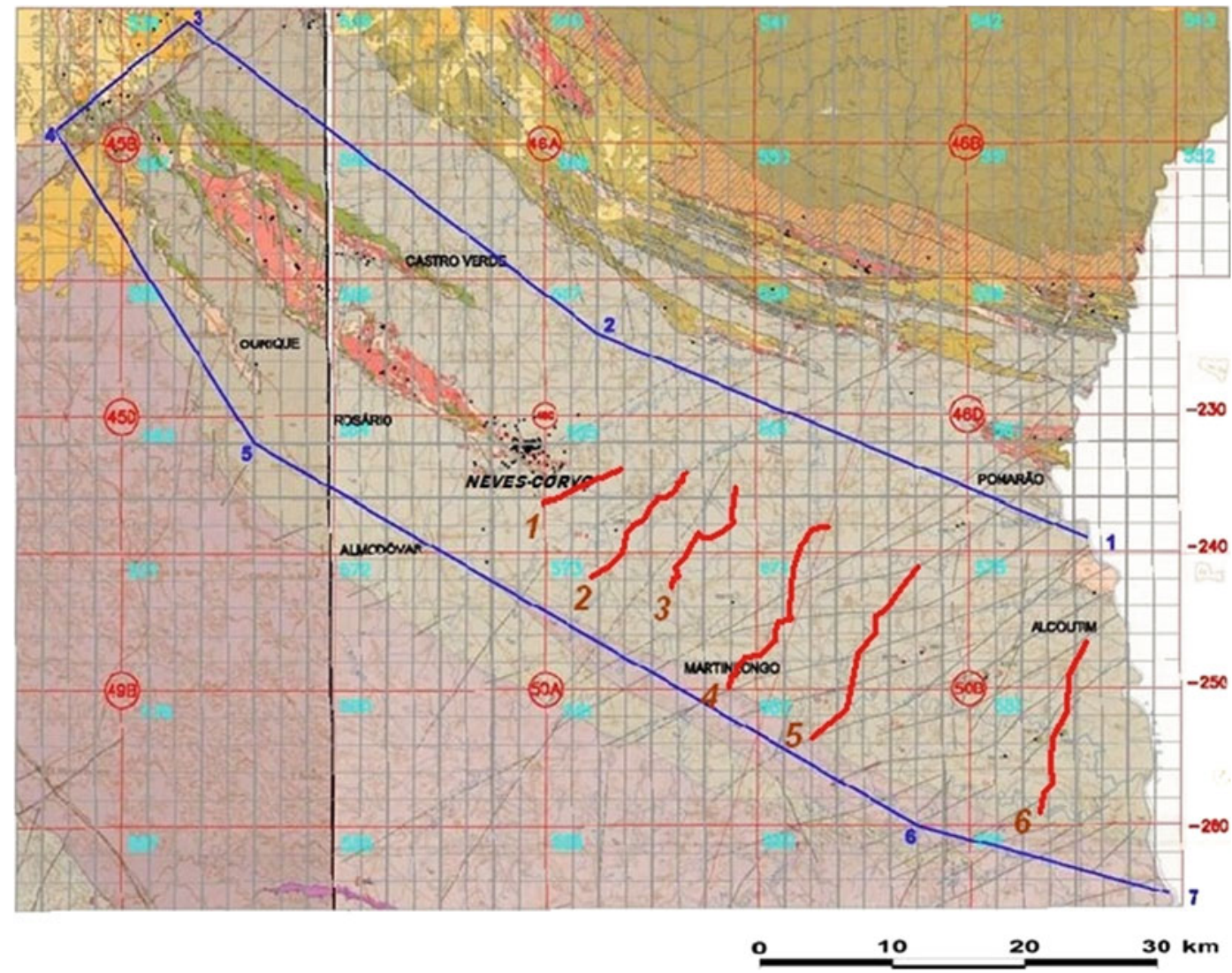

Fig. 11.8 Neves Corvo project area with location of the six 2D deep seismic reflection SW-NE profiles carried out by LNEG in the SE sector, between Neves Corvo mine and the Spanish border

holes, towards the SE, is consistently supported by all datasets. The contacts between PQG, VSC and the Mértola and Mira formations were identified in the seismic sections and confirmed in the drill holes. The Neves Corvo main thrust, identified in the Neves Corvo mine occurring almost adjacent to the VHMS ores, and dividing the sequence in an allochthonous block and a parautochthonous block (Figs. 11.9 and 11.10), also extends to the SE at least up to the Spanish border. In the Neves Corvo mine, immediately above the massive sulphide orebodies, sedimentary rock intervals with variable thickness and lateral extent can occur locally. They are made up of shales and greywackes of the Mértola Formation, which is therefore named there as "Mértola 2" to distinguish it from the Mértola Formation closer to surface. In the Alcoutim area a similar sequence consisting of rocks from the Mértola Formation at surface, followed at depth successively by VSC units, the Neves Corvo main thrust, a thin interval of Mértola Formation and VSC rocks was also identified, both in drill holes and in the seismic profiles, correlating very well with the general sequence identified at the mine.

All these surfaces were connected from one seismic section into another to define a 3D model (Figs. 11.11 and 11.12). We also note a good consistency between the interpretation of the Promine seismic profiles and the Somincor seismic profiles located further north. Taken together, they show the culminations of a pre-PQG unknown basement (Figs. 11.9 and 11.10), never drilled to date, along the Neves Corvo main thrust in agreement with the variations shown by 


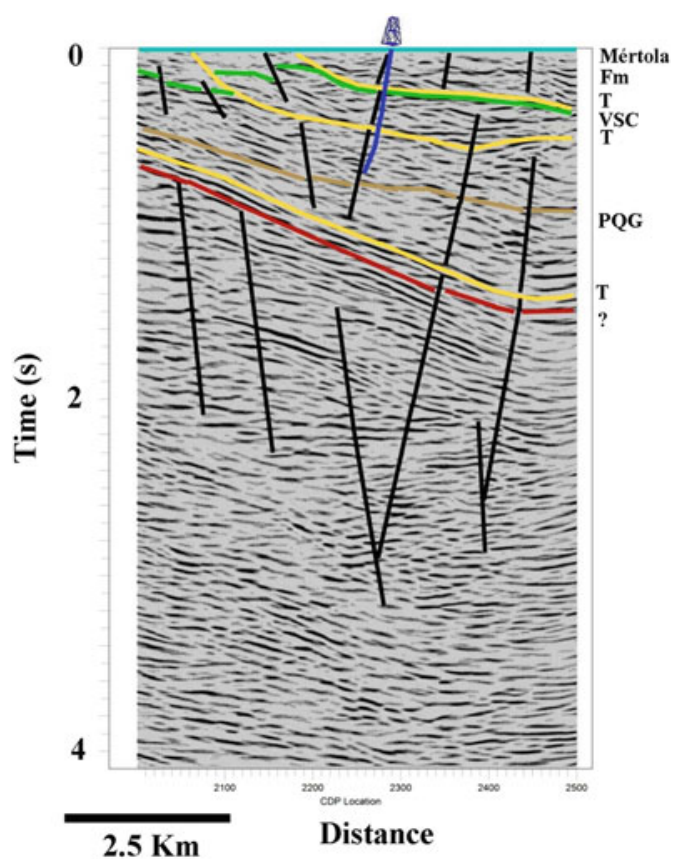

Fig. 11.9 Geological interpretation of 2D seismic reflection SW-NE profile 1 in the SE sector. Top of VSC (green), top of PQG (brown), T-thrust to SW (yellow), late Variscan faults (black), and unknown pre-basement surface (red); drill hole (blue). The Neves Corvo main thrust is the intermediate thrust potential field data. This basement was detected underneath the PQG in all six seismic sections. Late Variscan faults were also incorporated into the model. They displace the contacts between the PQG, VSC and the Mértola and Mira formations as well as the previous Variscan thrust faults. The late Variscan faults are extensional, strike-slip oblique, vertical to near-vertical faults that trend NE-SW, N-S and NNW-SSE (Figs. 11.11 and 11.12). The seismic data show that the principal faults are deeply rooted, being traceable down to $10 \mathrm{~km}$ depth (Fig. 11.10). The VSC that crops out in the Alcoutim area is interpreted to be at surface due to vertical movements along some of these fault planes, forming a horst type structure. According to the seismic and drill-hole geological data, the Neves Corvo main thrust was brought closer to surface in the Alcoutim area (where it is $\approx 1000 \mathrm{~m}$ deep) by the movements along the late Variscan faults. It is also noteworthy that these faults host $\mathrm{Cu}$ (and $\mathrm{Pb}$ ) sulphide veins with carbonates and barite mineralisations that were exploited in the 19th century (e.g. Barrigão, Ferrarias, Alcaria Queimada, Furnazinhas; Reiser et al. 2011; Matos et al. 2003) (see Fig. 11.24).
Fig. 11.10 Geological interpretation of 2D seismic reflection SW-NE profile 5 in the SE sector that includes the Neves Corvo main thrust. Symbols and patterns as in Fig. 11.9

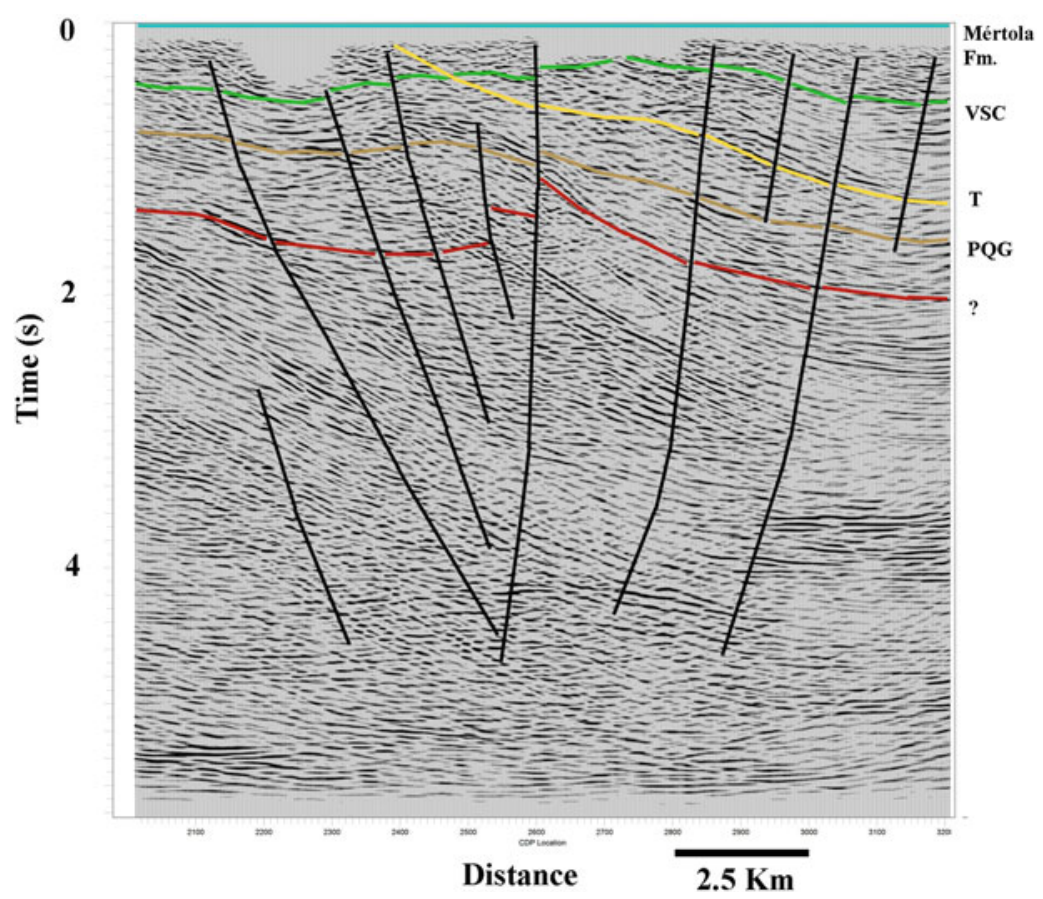




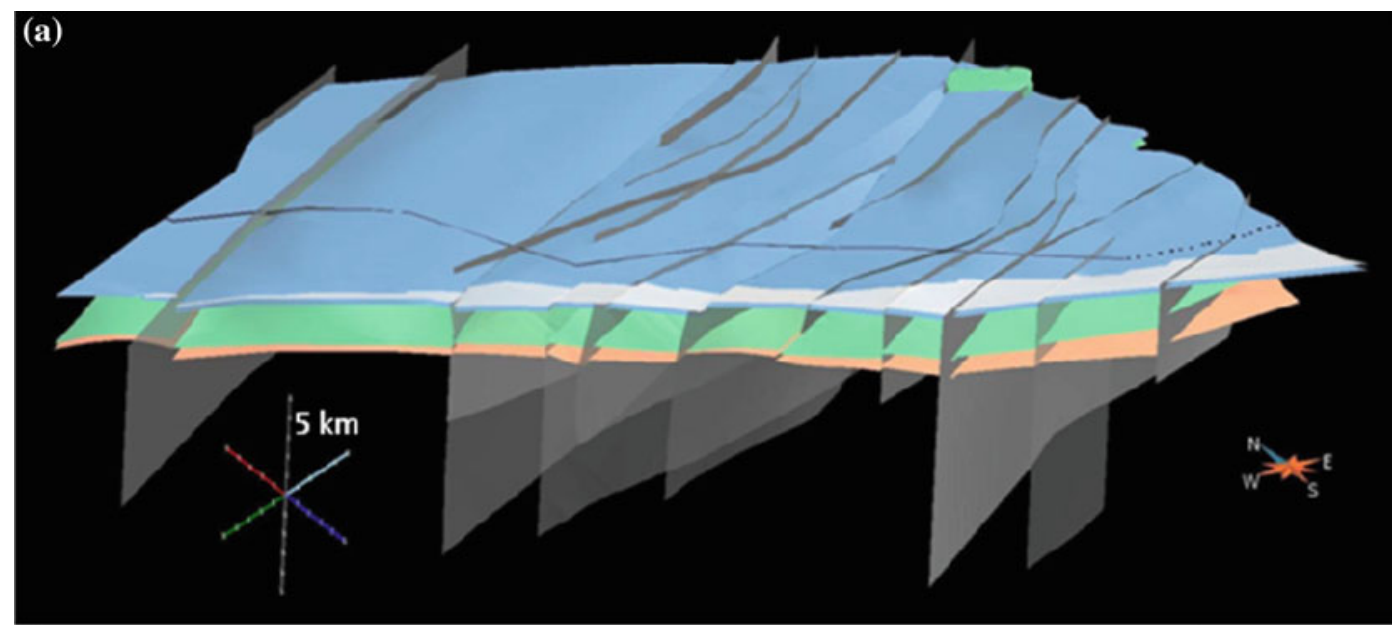

(b)

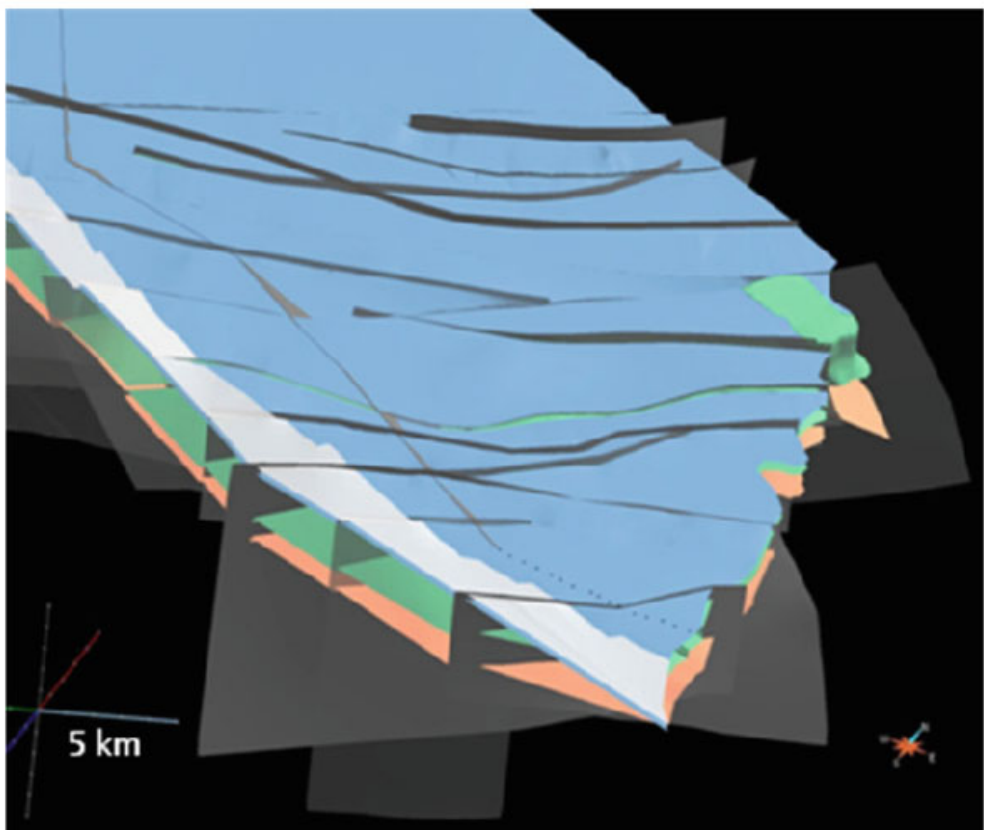

Fig. 11.11 3D (geological) model (a and b) of the entire SE area (above) and detail (below), containing tops of PQG (orange), VSC (green), Mértola (blue) and Mira

Connecting the area surrounding Neves Corvo mine and the SE area, and removing the upper Mértola and Mira flysch formations, a 3D model such as that of Fig. 11.13 is obtained, with a continuous Neves Corvo main thrust all along from west of the mine (west of the model) to the Spanish border, and the Late Variscan faults. If in (white) formations, and also exhibiting the longitudinal trace of the Neves Corvo main thrust (black-grey) and late Variscan faults (grey). Each cross arm is $5 \mathrm{~km}$ long

the same common area, the flysch rocks and VSC (except VHMS ores) are removed, a 3D model only containing PQG, Neves Corvo deposits above it and the Neves Corvo main thrust shows (viewed from the west) how close VHMS ores are to this thrust (Fig. 11.14) and therefore its regional significance for VHMS exploration. 

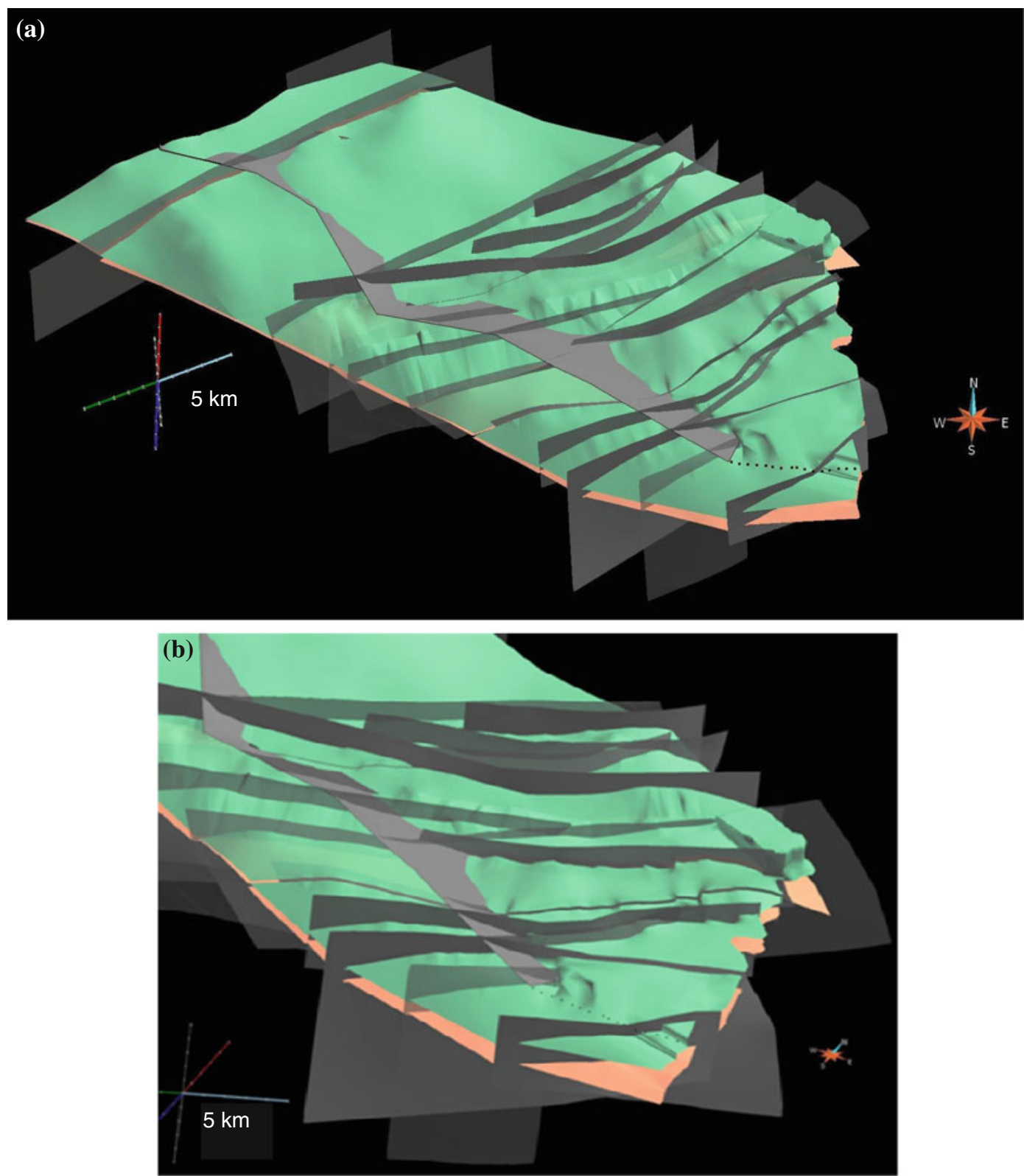

Fig. 11.12 Identical to Fig. 11.11, but with the 3D model (a and b) obtained after removal of the Mértola and Mira Flysch formations to better display the extension and

\subsubsection{The NW Sector}

The NW sector corresponds to the sector between the Neves Corvo Mine and the NW end of the project area. The area is characterized by the presence of the VSC rocks in the Castro attitude of the Neves Corvo main thrust and late Variscan faults. Symbols and patterns as in Fig. 11.11. Each cross arm is $5 \mathrm{~km}$ long

Verde, Rosário and Ourique (from NE to SW) antiform structures (Fig. 11.1; Oliveira et al. 2006). The VSC units are formed by sedimentary rocks and felsic and mafic volcanic rocks. The IPB rocks are affected by significant late Variscan strike-slip oblique faults striking 


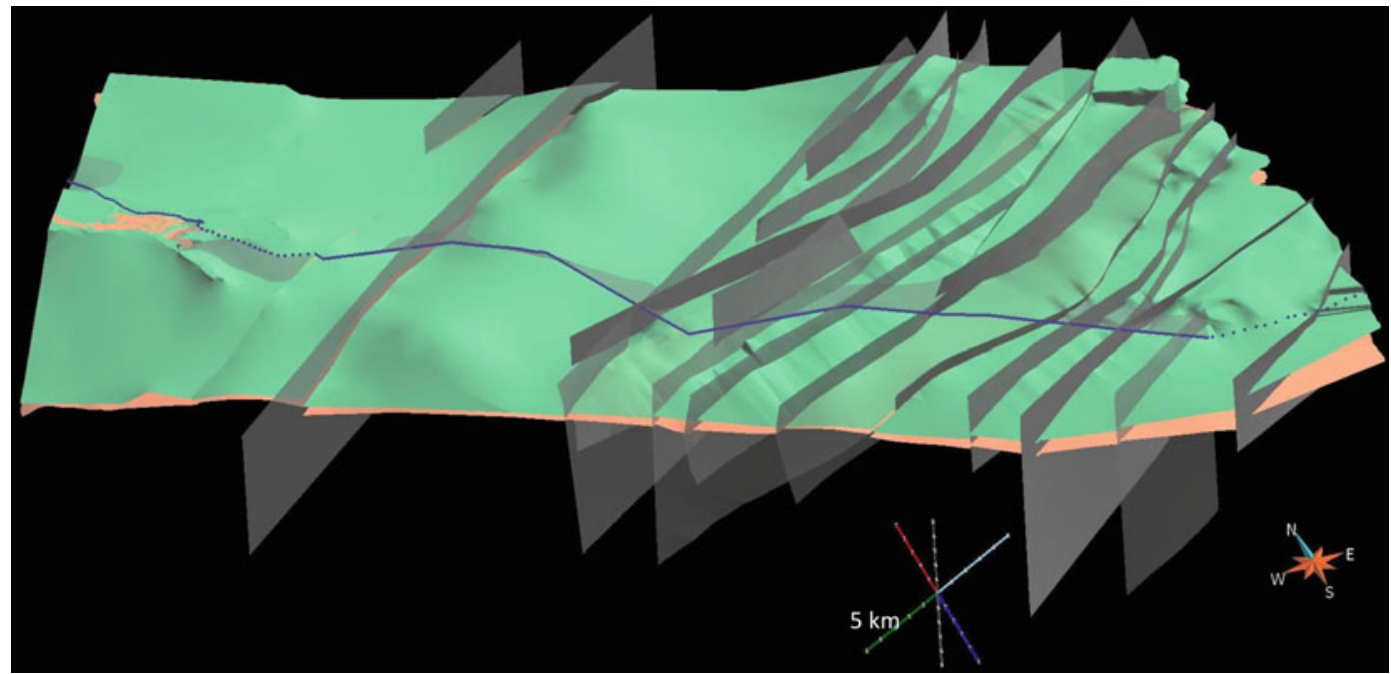

Fig. 11.13 3D model of joint Neves Corvo mine and the SE areas, after removal of the Mértola and Mira formations, displaying tops of PQG and VSC, Neves
Corvo main thrust (in blue) and late Variscan faults. Symbols and patterns as in Fig. 11.11. Each cross arm is $5 \mathrm{~km}$ long

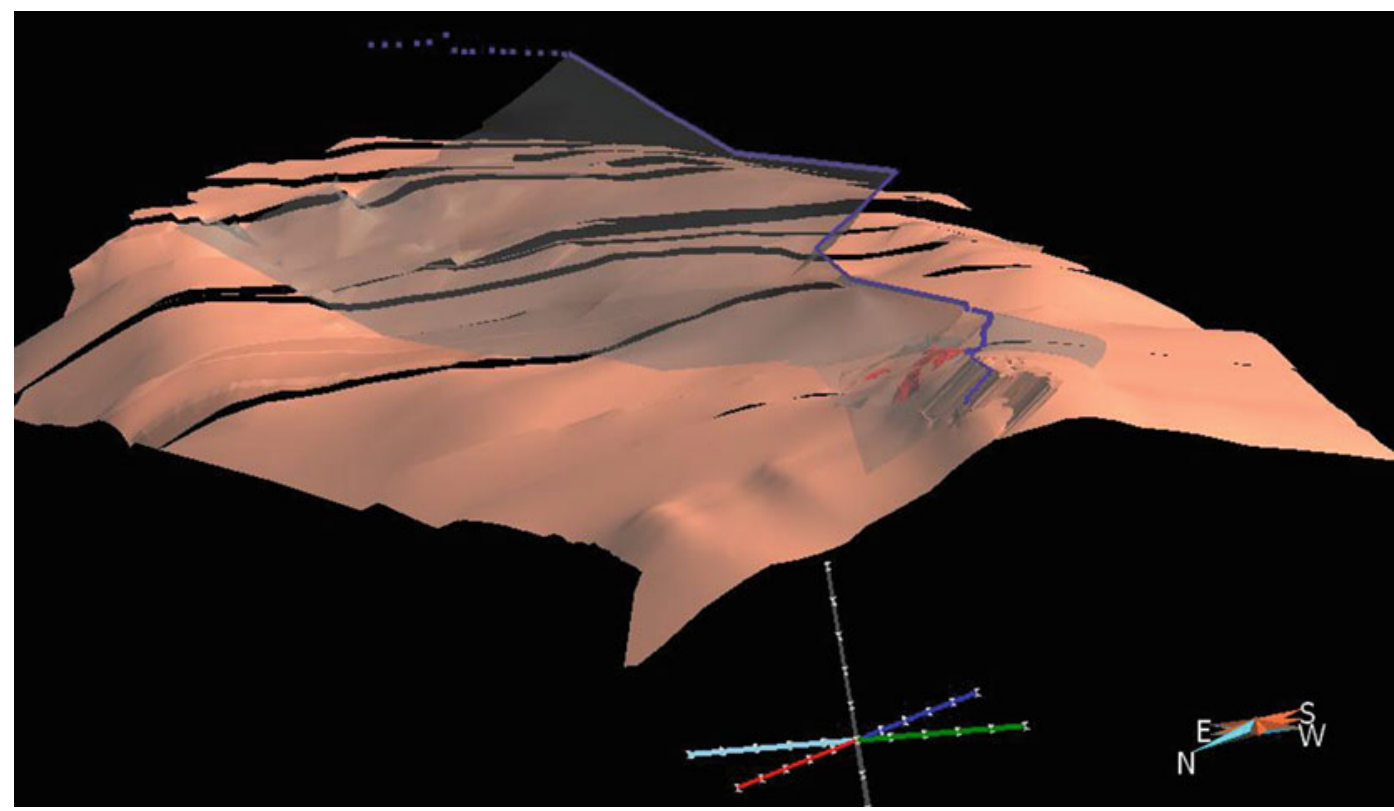

Fig. 11.14 3D model of same joint Neves Corvo mine and the SE areas, after removal of the Mértola and Mira formations, VSC (except VHMS ores) and late Variscan faults, to show, in a view from west, the top of PQG

NE-SW (sinistral) and N-S (dextral) (Figs. 11.15 and 11.16). The Messejana fault (Figs. 11.1, $11.15,11.16$ and 11.17), in the NW end of this sector, is the most significant of the former (orange), Neves Corvo VHMS ores (red) above, close to the Neves Corvo main thrust (blue). Each cross arm is $5 \mathrm{~km}$ long

group. This is a near-vertical, NE-SW-striking fault, that shows sinistral movement, displacing the Variscan structures for approximately $4 \mathrm{~km}$ (Schermerhorn et al. 1987; Leitão 1997), and 


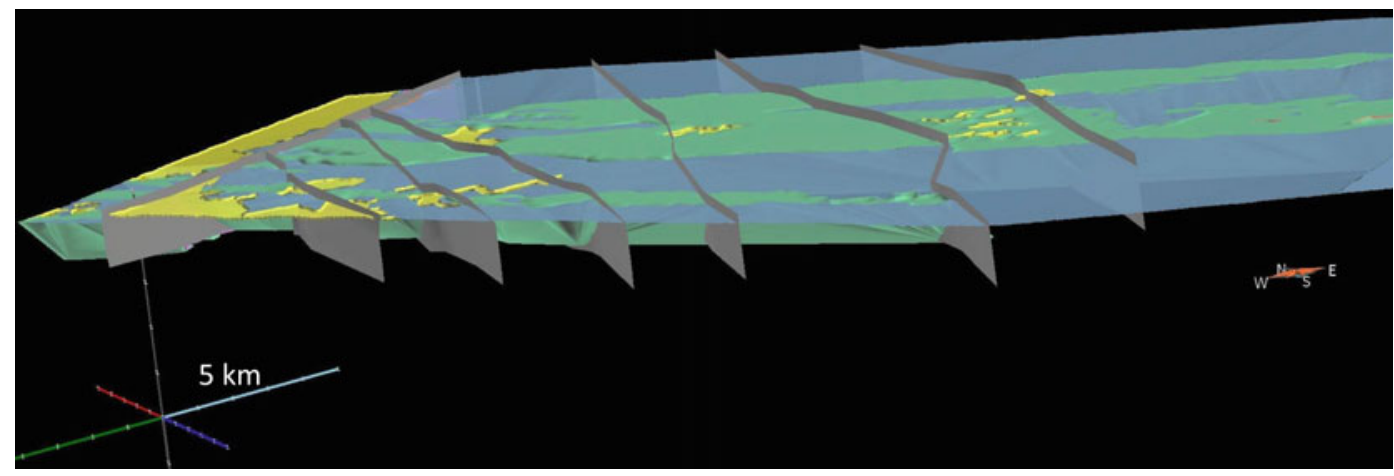

Fig. 11.15 3D model of the entire NW area showing part of PQG (orange) in the eastern end, VSC (green), Mértola Fm. (blue) and Cenozoic cover (yellow). Also NW-SE and NE-SW faults where the Messejana fault is the westernmost fault (grey). Each cross arm is $5 \mathrm{~km}$ long

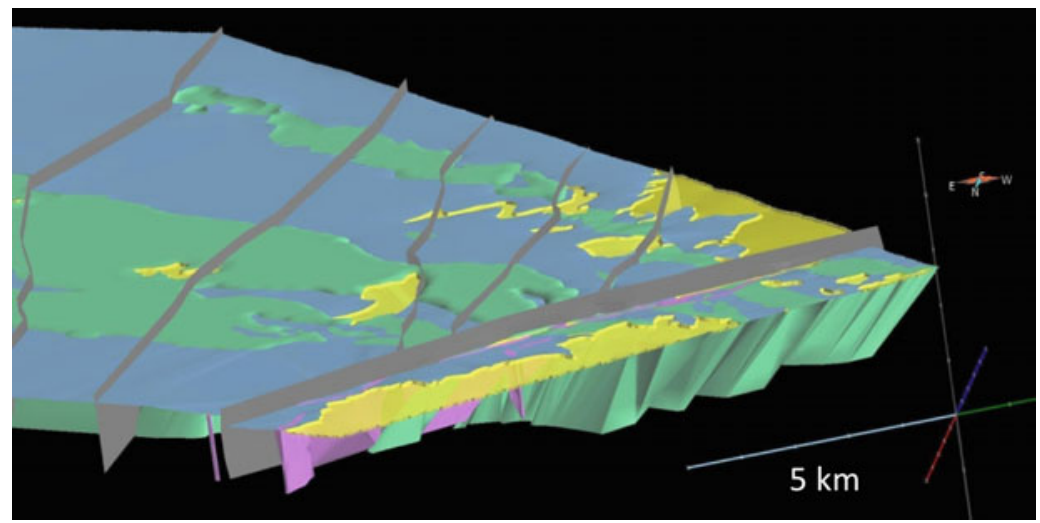

Fig. 11.16 3D model of the western part of the NW area (view from west), using same symbols and patterns as in Fig. 11.15. The prominent NE-SW Messejana fault,

also a downthrow of the NW fault block. Cenozoic sedimentary rocks are present in that block of the Messejana fault, forming part of the Sado-Alvalade Cenozoic basin (Schermerhorn et al. 1987; Oliveira et al. 2006). In the SE block minor Cenozoic overburden occurs and its distribution is controlled by late Variscan faults.

Located NE of Panóias, the small Montinho massive sulphide deposit crops out, rather close to the Messejana fault. The sulphides were exploited down to $50 \mathrm{~m}$ depth in the $1950 \mathrm{~s}$ by Mines d'Aljustrel (Matos and Rosa 2001). The Montinho mineralization consists of a stockwork hosted by black shales of Strunian age (Zélia Pereira 2013, personal communication). This age and recent exploration drill holes suggest that the accommodating a Jurassic dolerite dyke (violet) and with more developed Cenozoic cover deposits on the western fault block, is displayed. Each cross arm is $5 \mathrm{~km}$ long

PQG occurs at depth in the Montinho sector. In fact, the PQG also crops out near the Rosário village in the Promine area. Additionally, small syngenetic $\mathrm{Mn}$ mineralisations are hosted by VSC units in this NW sector. The 3D modelling of the NW area allows a better understanding of the VSC antiforms, which are complex and dominated by tectonic imbrication. This model is supported by geophysical EM data showing VSC black shale units gently dipping to NE. Drill hole data confirms the SW vergence of the structures also defined by large extension of the NE antiform limbs and minor development of the SW limbs. Figure 11.18 shows a 3D model of this NW area together with the other two areas. The 3D model in Fig. 11.19 correlates surface and 


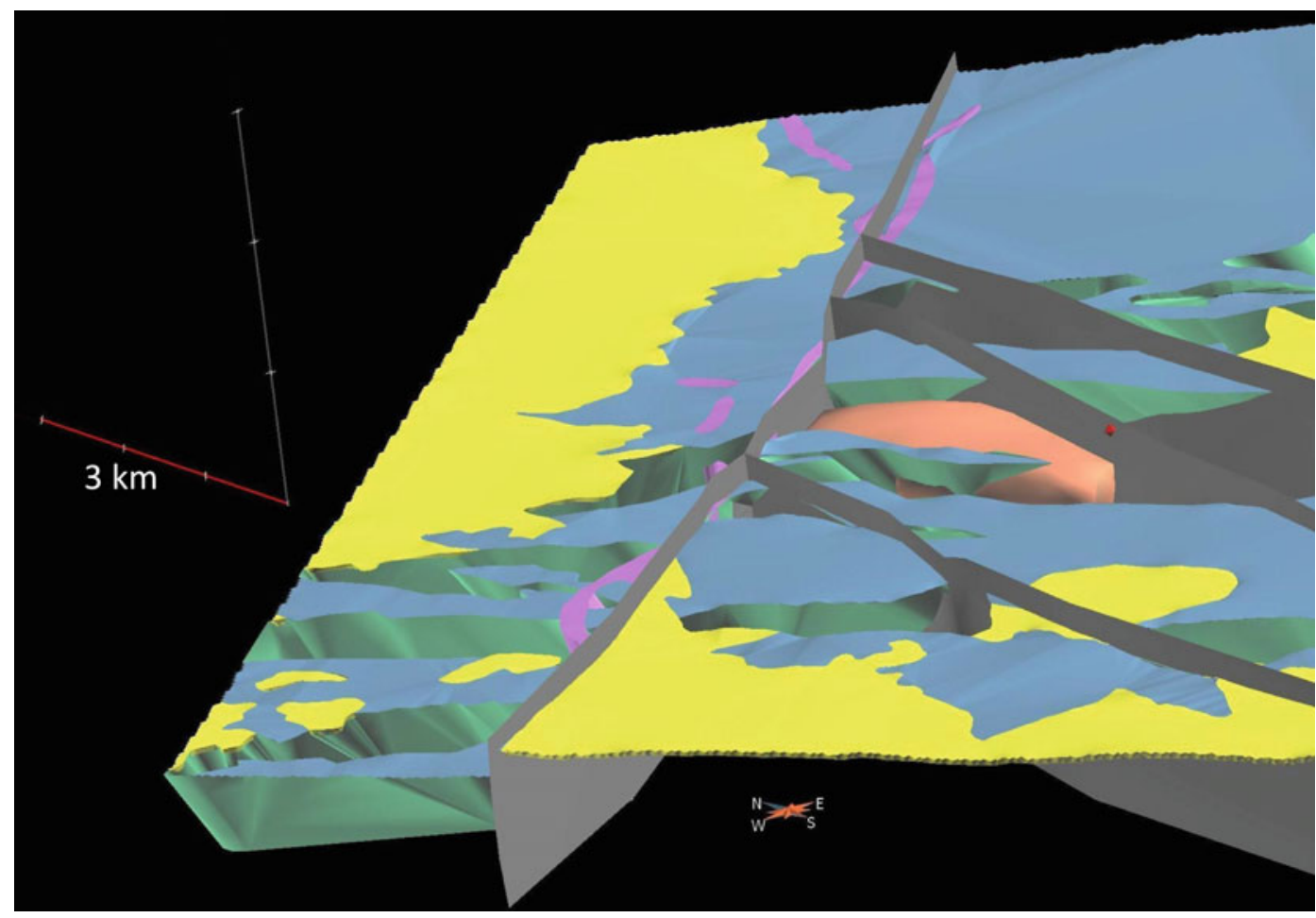

Fig. 11.17 Unroofed PQG (orange) at depth, VSC, Mértola Fm. and Cenozoic cover. Late Variscan faults, both NW-SE- and particularly the NE-SW striking Messejana fault accommodating a dolerite dyke are displayed. The small VSC-hosted Montinho VHMS deposit is shown (red dot). Symbols and patterns as in Fig. 11.16. Each cross arm is $3 \mathrm{~km}$ long

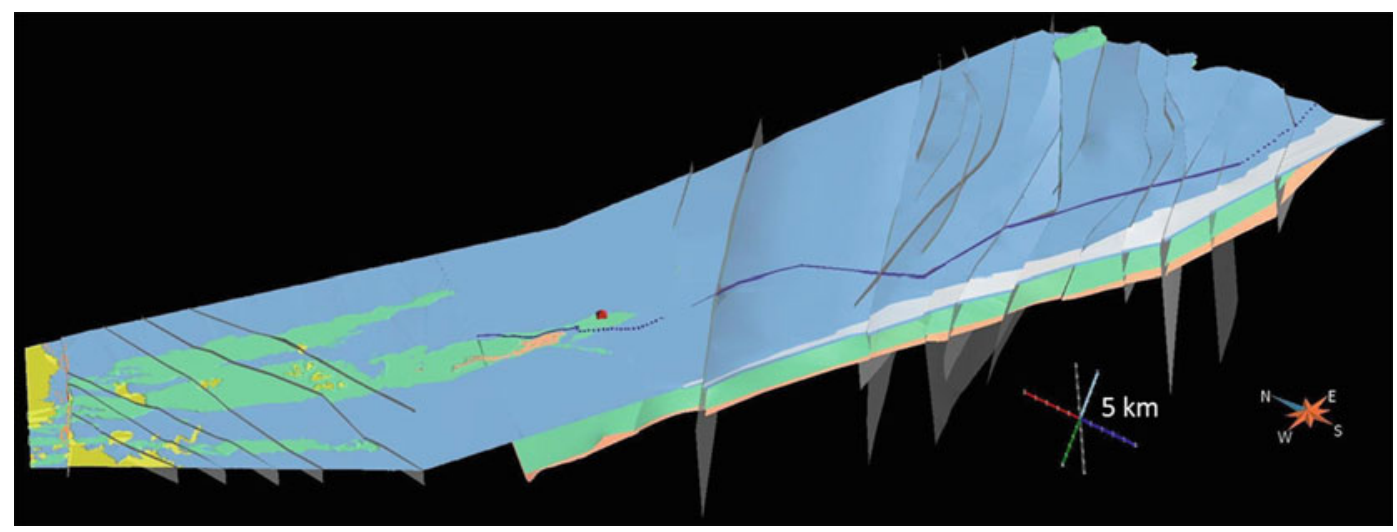

Fig. 11.18 3D model of the entire Neves Corvo area, showing tops of PQG, VSC, Mértola Fm. and Mira Fm. Neves Corvo mine shown as red/blue dot. Also, the
Neves Corvo main thrust (longitudinal blue line along the area) and late Variscan faults are displayed. Symbols and patterns as in Fig. 11.11. Each cross arm is $5 \mathrm{~km}$ long 


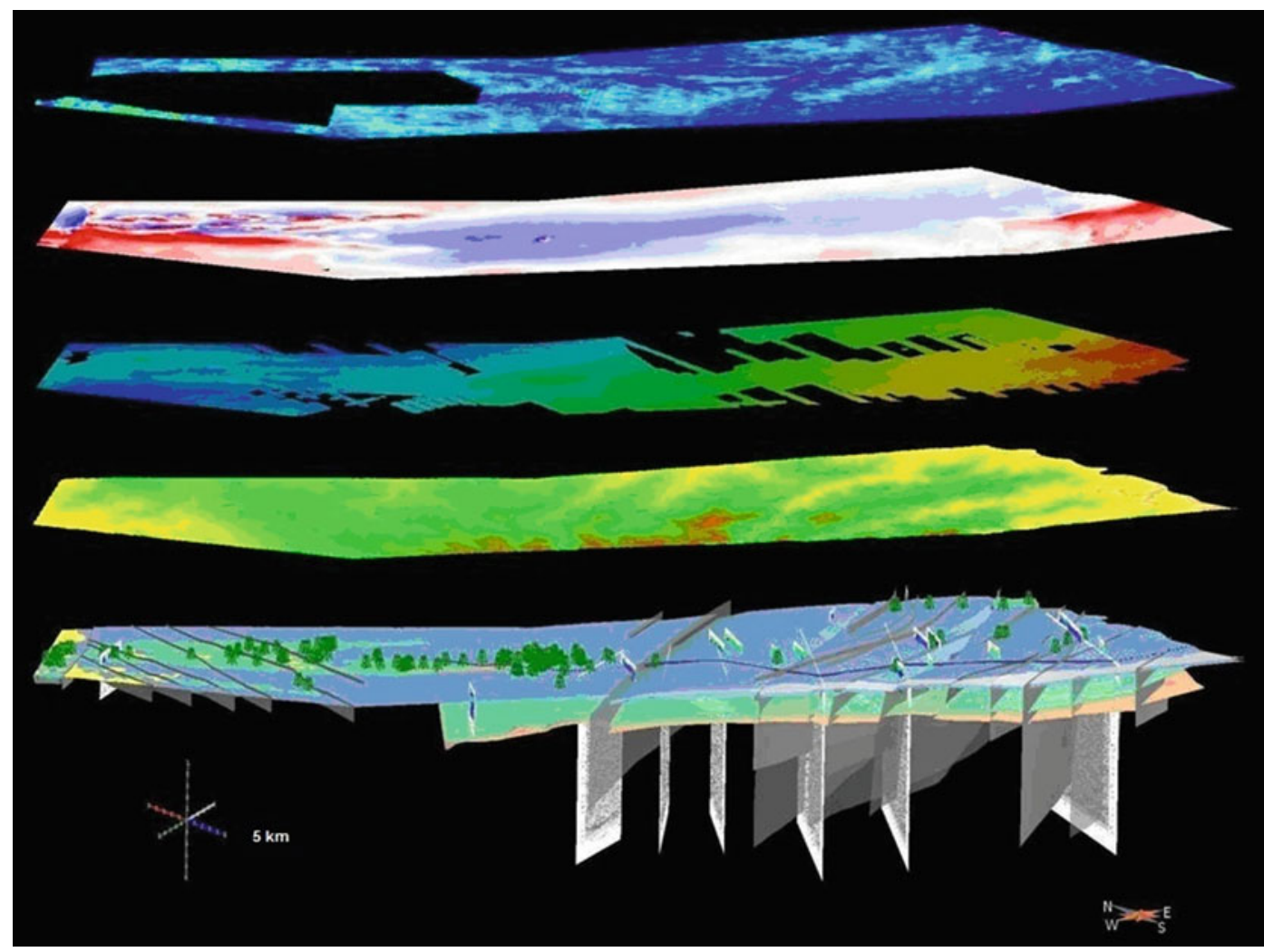

Fig. 11.19 3D geological-structural model of the Neves Corvo area, using the same symbols and patterns as in Fig. 11.18, but also including the drill holes used (dark green) and the six new 2D seismic reflection sections.

subsurface (drill holes) geology and structure with the six new 2D seismic reflection sections and with a digital terrain model as well as gravimetric, magnetic and radiometric data of the whole area used for this model.

\subsection{D Modelling of Project Area}

The 3D models obtained for the project area form the basis for reconstruction of the sequence of geological events from the time of deposition of the oldest geological unit occurring in the area until the present state. The main geological events recognized in the area were considered (e.g. massive sulphide formation, Variscan deformation, late Variscan faulting, among other
Detached layers, from bottom to top, of the digital terrain model, gravity (terrain), magnetics TMI, and radiometric maps for the entire area also used for the 3D model. Each cross arm is $5 \mathrm{~km}$ long

events) and a tight control of their ages was done where possible, in order to define the correct sequence of the main geological events. The age of the main sedimentary units of the IPB was already known in some regions of the project area. This knowledge is more comprehensive for the Neves Corvo mine where the age of the sedimentary units that occur beneath, above and intercalated in the massive sulphide pile helps to constrain the age of the mineralization (Oliveira et al. 2004). However, the amount of available data and its detail along the lithostratigraphic column varies significantly from location to location of the project area, and in fact for the majority of the project area there are no data. In order to increase the knowledge about some locations within the project area, new analyses of sedimentary rocks were performed. Regarding 
the volcanic rocks that constitute a significant part of the VSC, few absolute ages from zircon were available and only a few others were obtained during the project. The age of the late Variscan faults and of the mineralizations that they contain is more dubious, since there are no data available regarding the time of their formation. However, the field relations of these structures with the enclosing geological units and with structures are informative enough to confidently place their formation in relative time.

The sequence of the most relevant geological events considered in the comprehensive interpretation of the geological evolution of the Neves Corvo Project area started with the deposition of the sedimentary units that constitute the PQ Group. These rocks formed in a shallow marine platform (Oliveira et al. 1986) and constitute the substrate for the VSC. The top of the PQ Group has a Strunian age ( 362-360 Ma; Pereira et al. 2008) (Fig. 11.20) and at least in some locations of the IPB, during the Strunian the depositional setting was relatively deep, in anoxic conditions (Oliveira et al. 2004). It was also during the Strunian that the volcanism that sourced the lower volcanic sequence of VSC developed (Pereira et al. 2008; Matos et al. 2011). Detailed lithofacies mapping indicates that several submarine felsic volcanic centres formed in the basin (Fig. 11.21). It was also during the late Strunian that hydrothermal activity, close to the felsic volcanic centres, occurred and led to the formation of the giant Neves Corvo massive sulphide deposits, and of the smaller Algare and Montinho massive sulphide deposits. It is noteworthy that the mineralizing events of these three massive sulphide deposits have a similar age, and that this is the time for the formation of several other massive sulphide mineralizations in the IPB (Matos et al. 2011). The volcanic activity and deposition of volcanogenic sediments of the VSC occurred throughout the IPB until the Visean, 339-346 Ma, during which the widespread and abundant syngenetic Mn mineralizations formed in this part of the IPB (Fig. 11.22). A syn-orogenic flysch sequence occurs above the VSC rocks, represented by the Mértola and Mira Formations. All these rocks were deformed during the Variscan orogeny into a thin-skinned foreland fold and thrust belt (Silva et al. 1990; Quesada 1998) and a consequence of this deformation was the folding and faulting of the IPB rocks, including the mineral deposits and the formation of the Neves Corvo main thrust (Fig. 11.23) that was recognised to the SE of the mine, towards the Alcoutim area. Several late

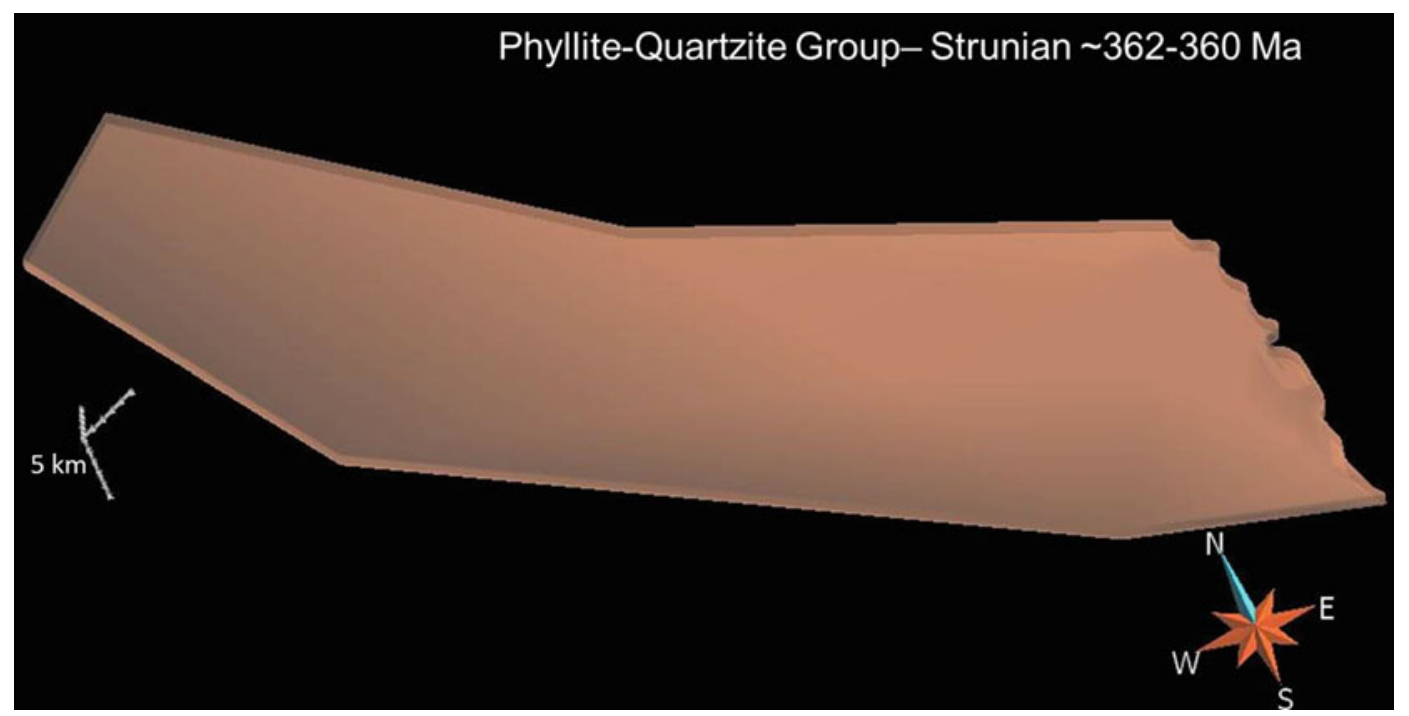

Fig. 11.20 4D model sequence: Phyllite-Quartzite Group in Strunian time ( $\approx 362-360 \mathrm{Ma})$ 


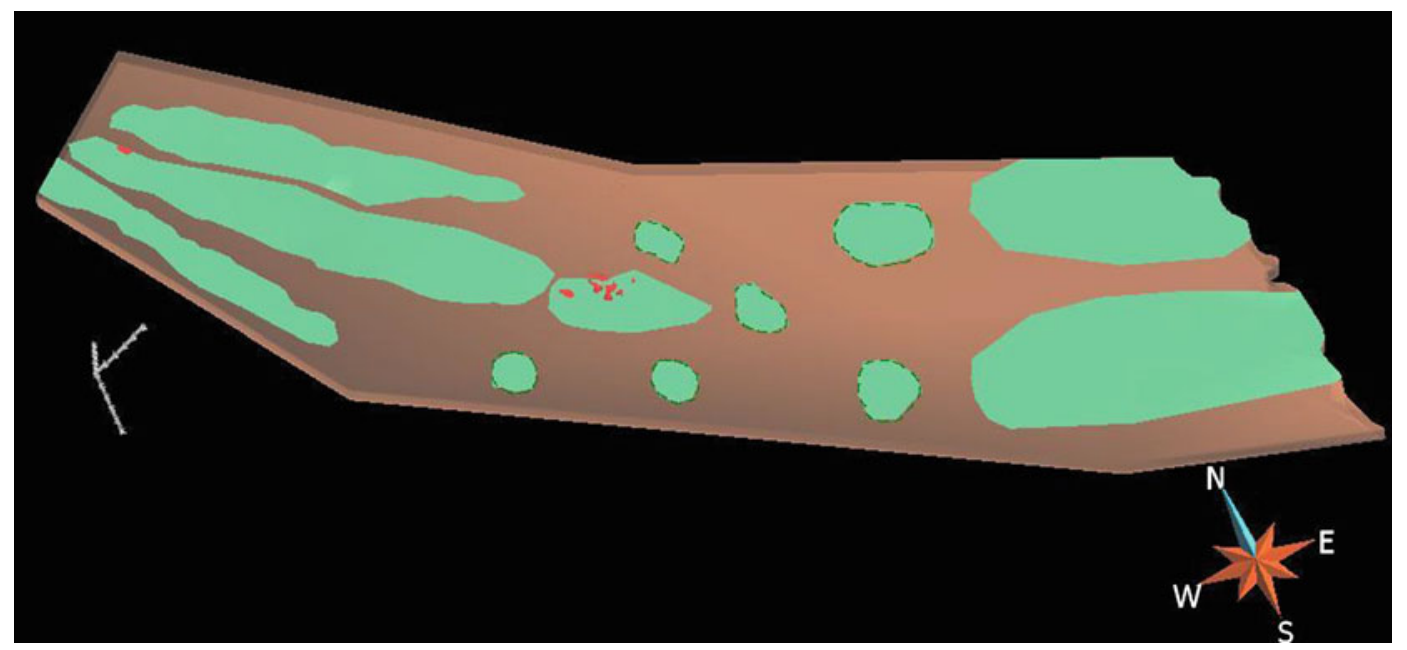

Fig. 11.21 4D model sequence: Volcanic Sedimentary Complex, including deposition of VHMS mineralization, in Strunian time $(\approx 362-360 \mathrm{Ma})$

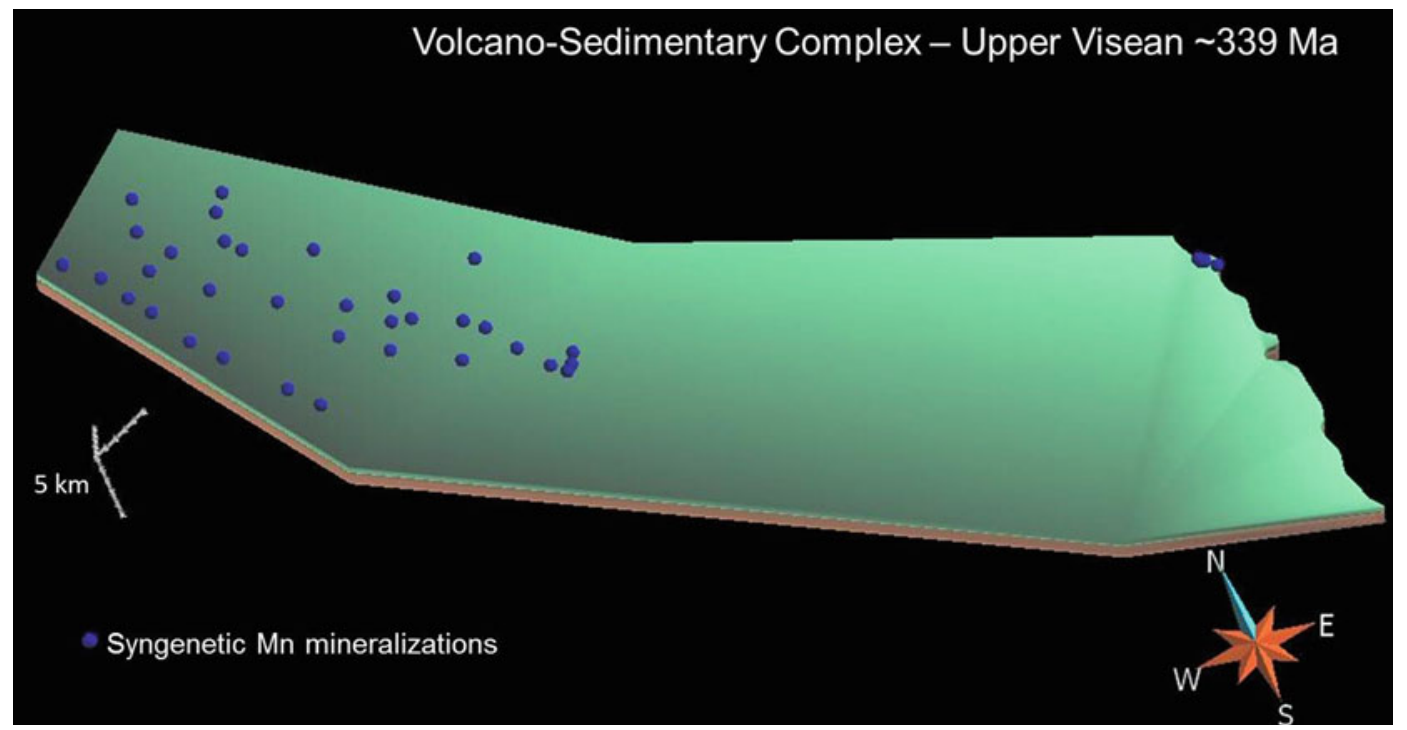

Fig. 11.22 4D model sequence: Volcanic Sedimentary Complex, including deposition of syngenetic Mn mineralization, in Visean time $(\approx 346-339 \mathrm{Ma})$

Variscan faults developed subsequently and disrupted the geological structures previously formed. These strike-slip oblique faults were identified throughout the Neves Corvo project area striking NE-SW to ENE-WSW (sinistral) and N-S to NNW-SSE (dextral), and are particularly conspicuous in the Alcoutim area (Fig. 11.24). These faults can host late Variscan $(\mathrm{Cu}$ and $\mathrm{Pb})$ sulphide mineralisations (Fig. 11.24), clearly defining a NW-SE trend to the SE of Neves Corvo mine. NW of the Neves Corvo project area (Fig. 11.24), the 


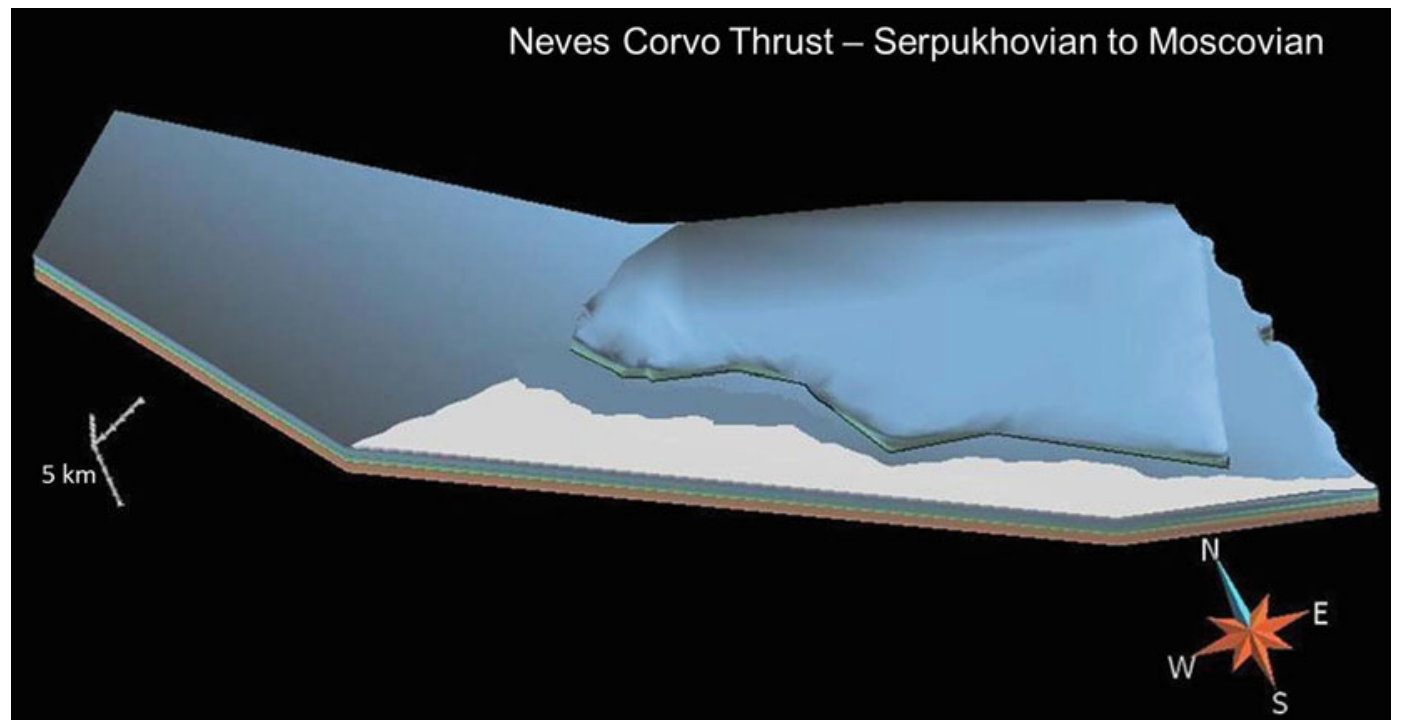

Fig. 11.23 4D model sequence: development of Neves Corvo main thrust in Serpukhovian to Moscovian time $(\approx 320 \mathrm{Ma})$

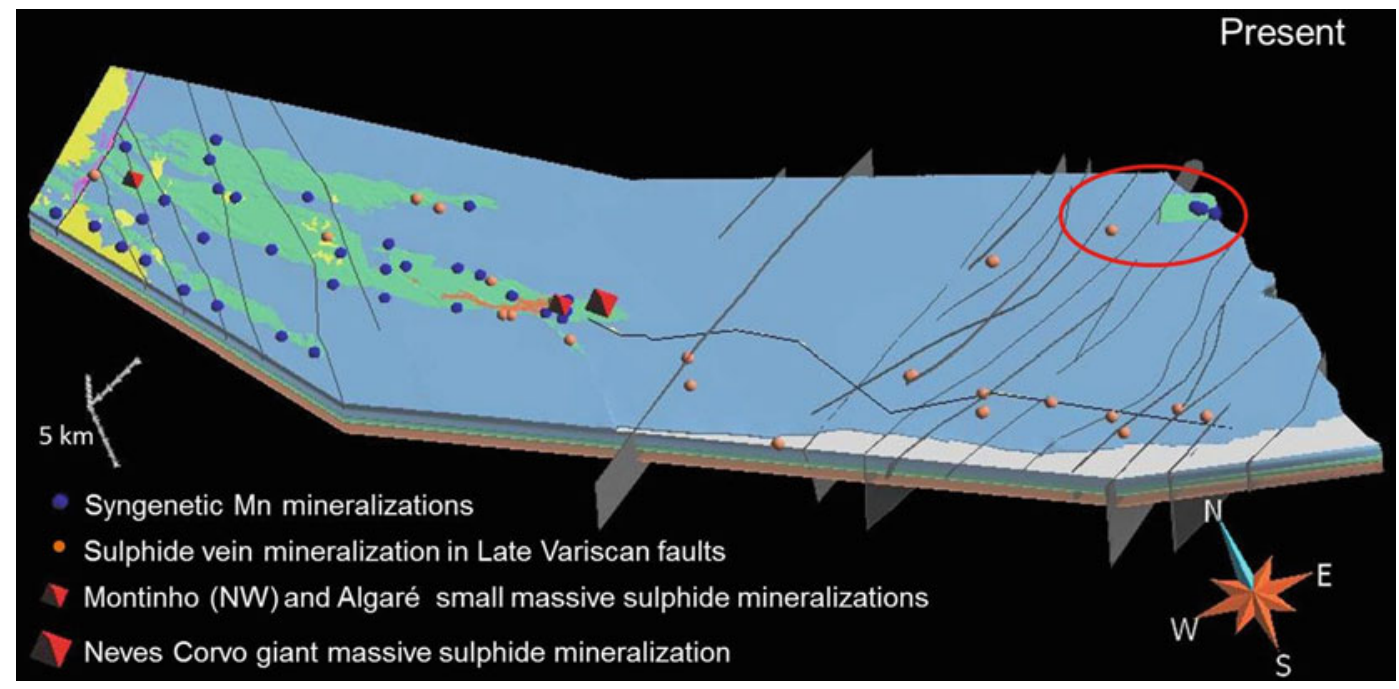

Fig. 11.24 4D model sequence: Status at Present time, exhibiting PQG, VSC and its VHMS mineralization, Mértola and Mira flysch formations, Neves Corvo main thrust, late Variscan faults with late Variscan vein-type $(\mathrm{Cu}$, etc.) sulphide mineralization and/or Jurassic dolerite dykes, and Cenozoic cover occurrence of the Messejana fault that extends for approximately $500 \mathrm{~km}$ in the Iberian peninsula, hosting dolerite intrusions of Jurassic age, is also noteworthy. Cenozoic sedimentary units included in the southern region of the Sado Alvalade Cenozoic Basin occur in grabens close to the Messejana fault (Fig. 11.1). 


\subsection{Predictive Modelling of Project Area and Exploration Significance}

\subsubsection{Regional Exploration and Predictive 2D Modelling}

After a criterion-based attempt to find the most appropriate data available from different sources, a predictive model has been produced for the study area. A 2D GIS integrated project was produced combining the most significant exploration data from the Rosário-Neves Corvo anticline, Ourique and Castro Verde anticlines and the Alcoutim/Odeleite region (Oliveira et al. 2006). Those data include soil geochemistry, magnetic data as its first vertical derivative, residual gravity data, and geological mapping $(1 / 200,000$ scale, Sheets 7 and 8 maps; Oliveira et al. 1984, 1992), including structural features such as major NW-SE thrusts and N-S, NE-SW and E-W Late Variscan strike-slip oblique faults. The regional trend of key tectonic structures such as the main Neves Corvo thrust (Leca et al. 1983; Relvas et al. 2006a; Oliveira et al. 2006; Pereira et al. 2008) was introduced in the predictive model, considering its exploration potential. The most important structural features are at least partially related with base metal mineralization, including volcanogenic massive sulphides such as Neves Corvo, Algaré and Montinho (Carvalho 1982; Barriga and Carvalho 1983; Oliveira et al. 1984, 1992: Carvalho et al. 1999) and Late Variscan vein-type deposits such as Ferrarias (Matos et al. 2003), Cortes Pereiras (Mateus et al. 2006) and Barrigão (Reiser et al. 2011). Studies of fluid inclusions in quartz, stibnite, and barite as well as sulphur isotopic compositions from Late Variscan vein-type base metal deposits reveal different sources of sulphur and deposition conditions of the mineralizations (Germann et al. 2003); different sources for the hydrothermal depositional fluids were also proposed by Relvas et al. (2006b) for the Neves Corvo deposit based on $\mathrm{O}-, \mathrm{H}-$ and $\mathrm{C}-$ isotope studies. The volume/tonnage of $\mathrm{Cu}$ in some VHMS deposits is significant, especially in Neves Corvo, the most Cu-rich IPB deposit (Relvas et al. 2006a). The massive sulphide deposits are associated to the VSC key exploration unit. Their stockworks are commonly hosted in VSC rocks, but also in the underlying Phyllite-Quartzite sedimentary unit rocks. The Late Variscan mineralized veins occur in the Flysch barren units (e.g. Mértola Formation of the Baixo Alentejo Flysch Group; Oliveira et al. 2006) and in the VSC units.

The surface geology was not considered for the predictive $2 \mathrm{D}$ modelling, with the exception of structural features, because the VSC is covered to a very significant part of the project area by a thick turbiditic sequence (Mértola and Mira formations). The lower weight that, in this case, would be given to this flysch-covered area could induce underestimation of the overall exploration potential, neglecting the influence of the VSC that is known to occur at depth. The distance from the occurrences of both volcanogenic and vein-type mineralization to either the Late Variscan faults or the main Neves Corvo thrust were calculated using the Near Distance tool in ArcGIS, originating a GIS variable. The "Two Conditions" settings were used during the processing, one where no distance restriction was imposed and the other where a $1500 \mathrm{~m}$ maximum distance was imposed. The geophysical data were combined using the available exploration information. The gravity and magnetic data were plotted to analyse the positive anomalies, which favour higher predictivity. In this respect, the highest predictive rate is given if gravity and magnetic positive anomalies are coincident when the two methods are combined. This is why the values higher than the 90th percentile of both methods added have the higher weight, and the respective areas were defined using GIS and the domains allocated as "area favourable by geophysics".

The main Neves Corvo thrust and the Late Variscan faults were buffered by an area $300 \mathrm{~m}$ wide, centered in the thrust/fault and those areas were also integrated in the predictive map. This restriction does not take into account that mineralized faults may not be mineralized in all its extension, but only where certain decompression 


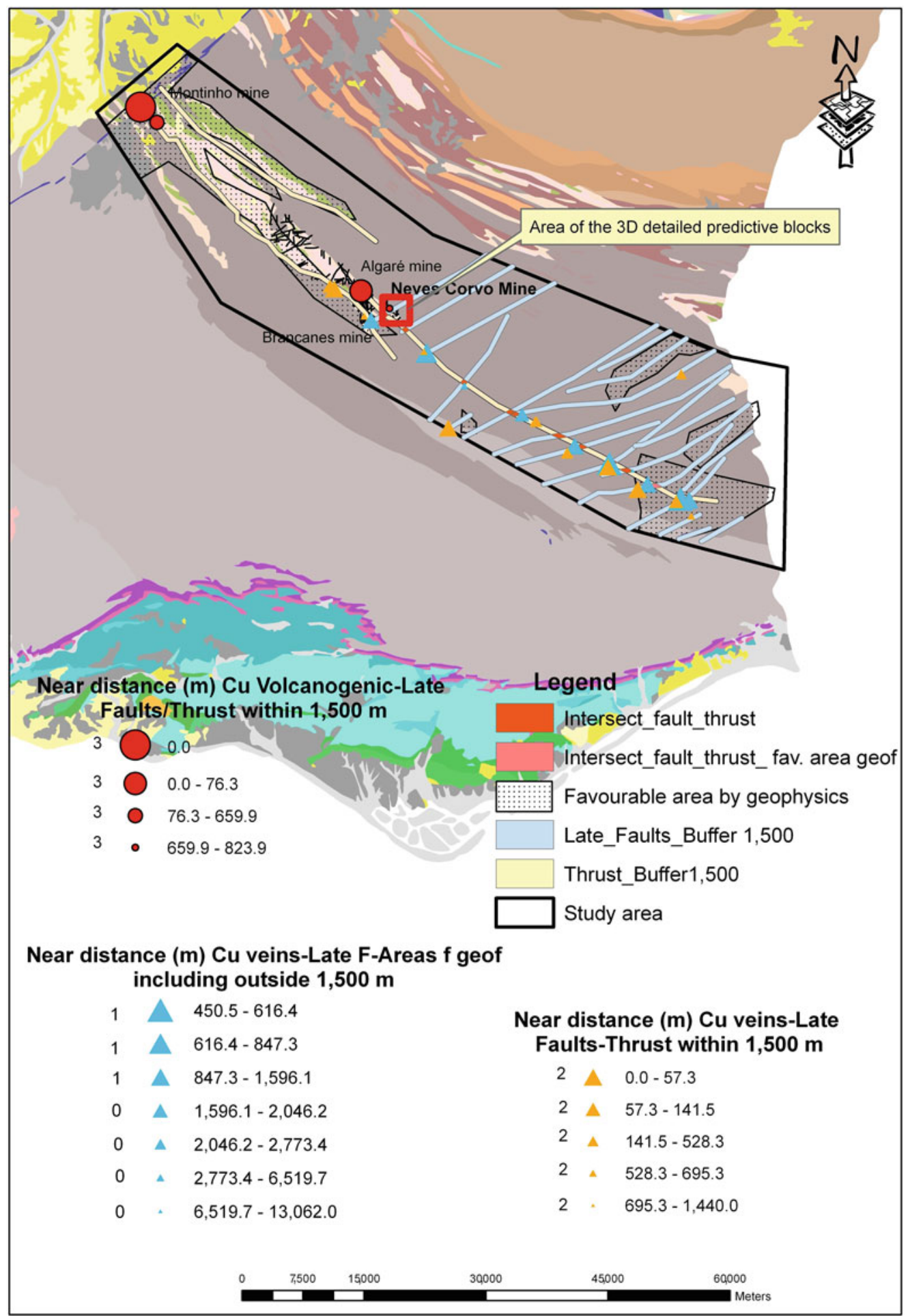

Fig. 11.25 2D predictive map of the study area. The Neves Corvo deposits were excluded to display the potential of the remaining area 
conditions occurred and with that type of faulting present locally in the host rock. The intersection areas among "areas favourable by geophysics", Late Variscan faults and Neves Corvo thrust were also integrated in the predictive map, and are referred to as "intersection" below. The near distance (within $1500 \mathrm{~m}$ ) from the volcanogenic deposits and the intersection of the previous referred to areas and thrust/faults were calculated and given the higher predictability rate. The near distance (within $1500 \mathrm{~m}$ ) between the Late Variscan vein type deposits plus the area favoured by geophysics, thrust and faults, were determined and given a median rate. The near distance (including outside the $1500 \mathrm{~m}$ ) between the Late Variscan vein-type deposits and the favourable areas given by geophysics, thrusts and faults, was determined and given the lower rate. Table 11.1 shows the variables used in calculation of the predictive map, Table 11.2 shows the weight criteria that defined the predictive area of focus for the exploration of $\mathrm{Cu}$.

Geochemistry was used to trace the natural pathfinders, with $\mathrm{Cu}$ taken as the main commodity mined in Neves Corvo and the most important commodity in the historical mining of the region, characterized by small $\mathrm{Cu}$ vein exploitations in the 19th century down to $200 \mathrm{~m}$ depth and by modern massive sulphide exploitation down to $900 \mathrm{~m}$ depth at the Neves Corvo mine (Somincor mining project, with production since 1987).

The deficient spatial distribution of the geochemical data at the scale of the study area precluded its use for the $2 \mathrm{D}$ predictive modelling. However, because of its great exploration significance, it is taken in consideration in the final decision. Therefore, with the available information from different geochemical campaigns that were performed in the NW-SE Neves Corvo-Rosário volcanic axis/structure, a factorial analysis with varimax rotation was applied and the Kaiser (1960) criteria used. Table 11.3 shows the results and the variation in the superficial pathfinders $(\mathrm{Cu}$ and related elements) along that volcanic axis/structure from the Montinho area, extending to the SE into the Garronchal, Zambujeira and finally into the Neves Corvo area. The results are strongly dependent on the chemical elements analysed, which restricts greatly any possible conclusions that can be drawn.

Based on the available information the Neves Corvo thrust and the alignment of the outcropping axis/structure at the surface, are the most important guides for mineral exploration in the study area. The highly predictive areas for VHMS deposits were coincident with this alignment. A special conclusion is the fact that the extension of the Neves Corvo thrust, obtained in the $3 \mathrm{D}$ modelling and applied in the predictive

Table 11.1 Selected variables for predictive modelling

\begin{tabular}{l|l}
\hline Methods & Conditions \\
\hline $\begin{array}{l}\text { Favourable area given by geophysics } \\
\text { Gravimetry+magnetics } \\
\text { Gravimetry-magnetics }\end{array}$ & $\begin{array}{l}\text { From above 90 \%o positive when adding } \\
\text { and negative when subtracting }\end{array}$ \\
\hline $\begin{array}{l}\text { Late Variscan faults } \\
\text { Thrusts }\end{array}$ & Buffer $1500 \mathrm{~m}$ \\
\hline $\begin{array}{l}\text { Nearest distance from volcanogenic deposits and intersection of } \\
\text { thrusts and Late Variscan faults }\end{array}$ & Buffer $1500 \mathrm{~m}$ \\
\hline $\begin{array}{l}\text { Nearest distance from vein type deposits and intersection of thrusts } 1500 \mathrm{~m} \text { distance } \\
\text { and Late Variscan faults }\end{array}$ & Within $1500 \mathrm{~m}$ distance \\
\hline $\begin{array}{l}\text { Nearest distance from vein type deposits and intersection of thrusts } \\
\text { and Late Variscan faults and favourable area given by geophysics }\end{array}$ & Within the $1500 \mathrm{~m}$ distance \\
\hline $\begin{array}{l}\text { Nearest distance from vein type deposits and intersection of thrusts } \\
\text { and Late Variscan faults and favourable area given by geophysics }\end{array}$ & Outside the $1500 \mathrm{~m}$ range \\
\hline
\end{tabular}


Table 11.2 Predictive weights

\begin{tabular}{l|l|l}
\hline Methods & Weight \\
\hline $\begin{array}{l}\text { Nearest distance from volcanogenic deposits and intersection of thrusts and Late } \\
\text { Variscan faults }\end{array}$ & $\begin{array}{l}\text { Within } 1500 \mathrm{~m} \\
\text { distance }\end{array}$ & 3 \\
\hline $\begin{array}{l}\text { Nearest distance from vein type deposits and intersection of thrusts and Late } \\
\text { Variscan faults }\end{array}$ & $\begin{array}{l}\text { Within } 1500 \mathrm{~m} \\
\text { distance }\end{array}$ & 2 \\
\hline $\begin{array}{l}\text { Nearest distance from vein type deposits and intersection of thrusts and Late } \\
\text { Variscan faults and favourable area given by geophysics }\end{array}$ & $\begin{array}{l}\text { Within the } 1500 \mathrm{~m} \\
\text { distance }\end{array}$ & 1 \\
\hline $\begin{array}{l}\text { Nearest distance from vein type deposits and intersection of thrusts and Late } \\
\text { Variscan faults and favourable area given by geophysics }\end{array}$ & $\begin{array}{l}\text { Outside the } 1500 \mathrm{~m} \\
\text { range }\end{array}$ & 0 \\
\hline
\end{tabular}

3 the higher weight; 2 medium weight, 1 lower weight, 0 no influence in predictivity

Table 11.3 Factorial analysis of PC extraction and representation of the $\mathrm{Cu}$ probable pathfinders in the area, considering the elements used in the calculation

\begin{tabular}{|c|c|c|}
\hline $\begin{array}{l}\text { Area (\% variance explained in the } 1 \text { st } 2 \\
\text { axis) }\end{array}$ & Total elements used in PCA & $\begin{array}{l}\text { Correlated with the occurrence of } \\
\mathrm{Cu}(>0.7) \text { and PC extraction using } \\
\text { Kaiser (1960) criteria }\end{array}$ \\
\hline Moitinhos (62 \%) & $\begin{array}{l}\text { As, Ba, Co, Cr, Cu, Fe, Mg, } \\
\text { Mn, Ni, P, Pb, Rb, S, Sc, V, } \\
\text { Zn }\end{array}$ & (Axis 2) As, $\mathbf{C u}, \mathrm{Pb}, \mathrm{Zn}$ \\
\hline Garrochal (54 \%) & $\begin{array}{l}\mathrm{Cu}, \mathrm{Pb}, \mathrm{Zn}, \mathrm{Ni}, \mathrm{Co}, \mathrm{As}, \mathrm{Fe} \\
\mathrm{Mn}, \mathrm{Ba}, \mathrm{Cr}, \mathrm{V}, \mathrm{Al}, \mathrm{Sr}, \mathrm{Nb}, \mathrm{Sc}\end{array}$ & (Axis 1) $\mathrm{Cu}, \mathrm{Ni}, \mathrm{Co}, \mathrm{Fe}, \mathrm{Mn}, \mathrm{V}, \mathrm{Al}$ \\
\hline Zambujeira (64 \%) & $\begin{array}{l}\mathrm{Cu}, \mathrm{Pb}, \mathrm{Zn}, \mathrm{Ni}, \mathrm{Co}, \mathrm{As}, \mathrm{Fe} \\
\mathrm{Mn}, \mathrm{Ba}, \mathrm{Cr}, \mathrm{V}, \mathrm{Al}, \mathrm{Nb}\end{array}$ & (Axis 1) $\mathbf{C u}, \mathrm{Zn}, \mathrm{Ni}, \mathrm{As}, \mathrm{Fe}, \mathrm{Cr}, \mathrm{Al}$ \\
\hline Neves Corvo (samples from 1998) (60\%) & $\begin{array}{l}\mathrm{Cu}, \mathrm{Pb}, \mathrm{Zn}, \mathrm{Ni}, \mathrm{Co}, \mathrm{Mn}, \mathrm{Fe} \\
\mathrm{As}, \mathrm{V}, \mathrm{Ca}, \mathrm{P}, \mathrm{Cr}, \mathrm{Mg}, \mathrm{Ba}, \mathrm{Ti} \\
\mathrm{Al}, \mathrm{Na}, \mathrm{Sn}, \mathrm{Nb}, \mathrm{Sc}\end{array}$ & (Axis 2) $\mathbf{C u}, \mathrm{Pb}, \mathrm{Zn}, \mathrm{As}, \mathrm{Sn}$ \\
\hline $\begin{array}{l}\text { Neves Corvo area before start of mine } \\
\text { production (archived samples from the } \\
70 \text { s analysed recently) }(56 \%)\end{array}$ & $\begin{array}{l}\mathrm{Cu}, \mathrm{Pb}, \mathrm{Zn}, \mathrm{Ni}, \mathrm{Co}, \mathrm{Mn}, \mathrm{Fe} \\
\mathrm{As}, \mathrm{V}, \mathrm{Cr}, \mathrm{Mg}, \mathrm{Ba}, \mathrm{Ti}, \mathrm{Nb}\end{array}$ & (Axis 2) $\mathbf{C u}, \mathrm{Pb}, \mathrm{Zn}, \mathrm{Co}$ \\
\hline
\end{tabular}

maps, coincides spatially with the main alignment of the $\mathrm{Cu}$ mineralizations identified by the authors as vein-type late Variscan mineralisations. Also, the intersection of the Neves Corvo thrust and the late Variscan faults is sometimes not far from these mineral occurrences. Sulphide remobilization during late Variscan deformation must be properly understood, considering the mineral dispersion from a giant sulphide deposit (Neves Corvo) or from other possible hidden VHMS ores. These results, combined in the 2D predictive map, seem to be of great exploration importance (Fig. 11.25).

\subsubsection{D Predictive Modelling of Neves Corvo Mine Area}

The previously produced 2D predictive map needs further developments at depth. Because most of the area is covered by the thick flysch of the Mértola Fm., it is appropriate to go over the data location and information available relative to VSC below that formation. The exploration drill hole data show a variable distribution of the VSC, controlled by late Variscan faults and regional folds. Because different formations have different densities and the massive sulphides 


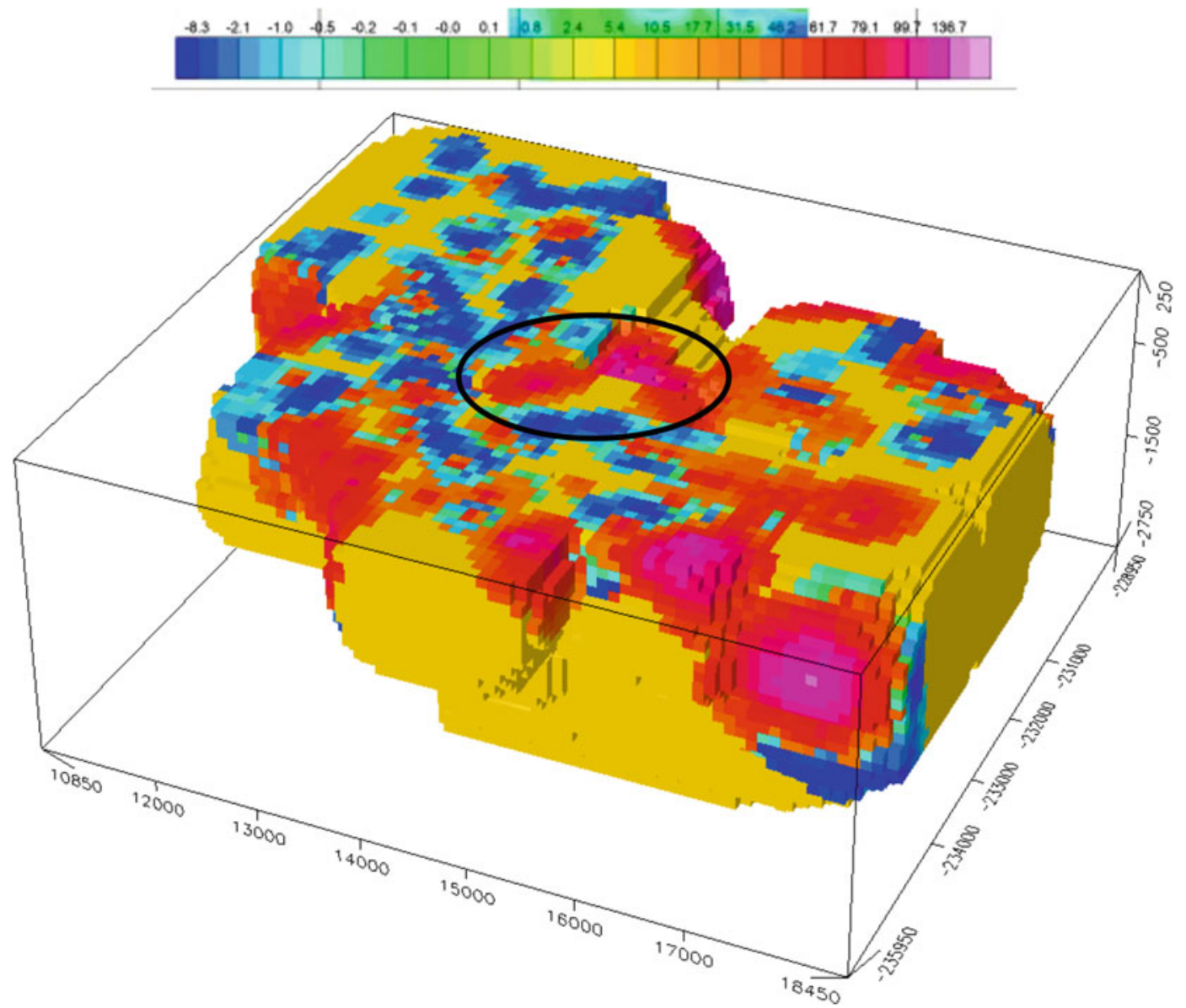

Fig. 11.26 $3 \mathrm{D}$ densities from gravity inversion in the Neves Corvo mine area

usually have higher density than the host rocks, densities at depth were investigated relative to a restricted area around the Neves Corvo mine. A 3D density model was calculated by applying an inversion methodology (Camacho et al. 2002) to the gravity data. The gravity dataset allowed a resolution grid of $100 \mathrm{~m}$, given that this was the average distance between data points. The voxel of the calculated densities produced using 3D kriging is shown in Fig. 11.26.

The geochemical information was compiled from previous exploration campaigns that included soil geochemistry surveys and drill hole rock geochemical analysis. The information was selected using only drill holes where $\mathrm{Cu}$ results were reported in weight \%. A 3D grid was built and, also at this stage, several drill holes were discarded due to the distance of interpolation. The 3D voxel is composed by cubic cells whose values were determined using linear interpolation between the values of the eight voxel points, which form the corners of the cube. The size of the edges of the cubes is $50 \mathrm{~m}$ to obtain a continuous image. The resulting calculation indicates a trend of $\mathrm{Cu}$ open in both sides. This trend and its extensions were considered the highest level of predictive VHMS volume (Fig. 11.27). Even though the geochemistry and density models were calculated using very different approaches, it can be observed that the places where high density and high $\mathrm{Cu}$ concentration coincide are places where the predictability values are considered to be the highest. This corresponds to one of the known massive sulphide 

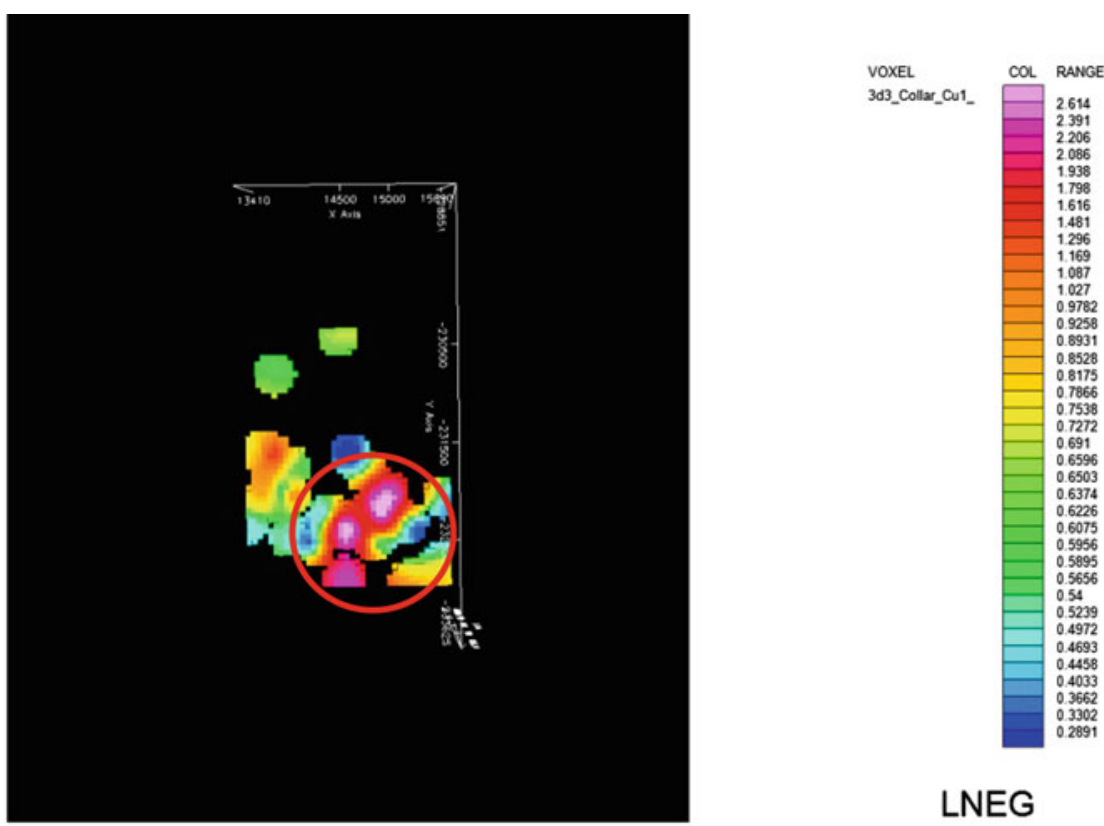

LNEG

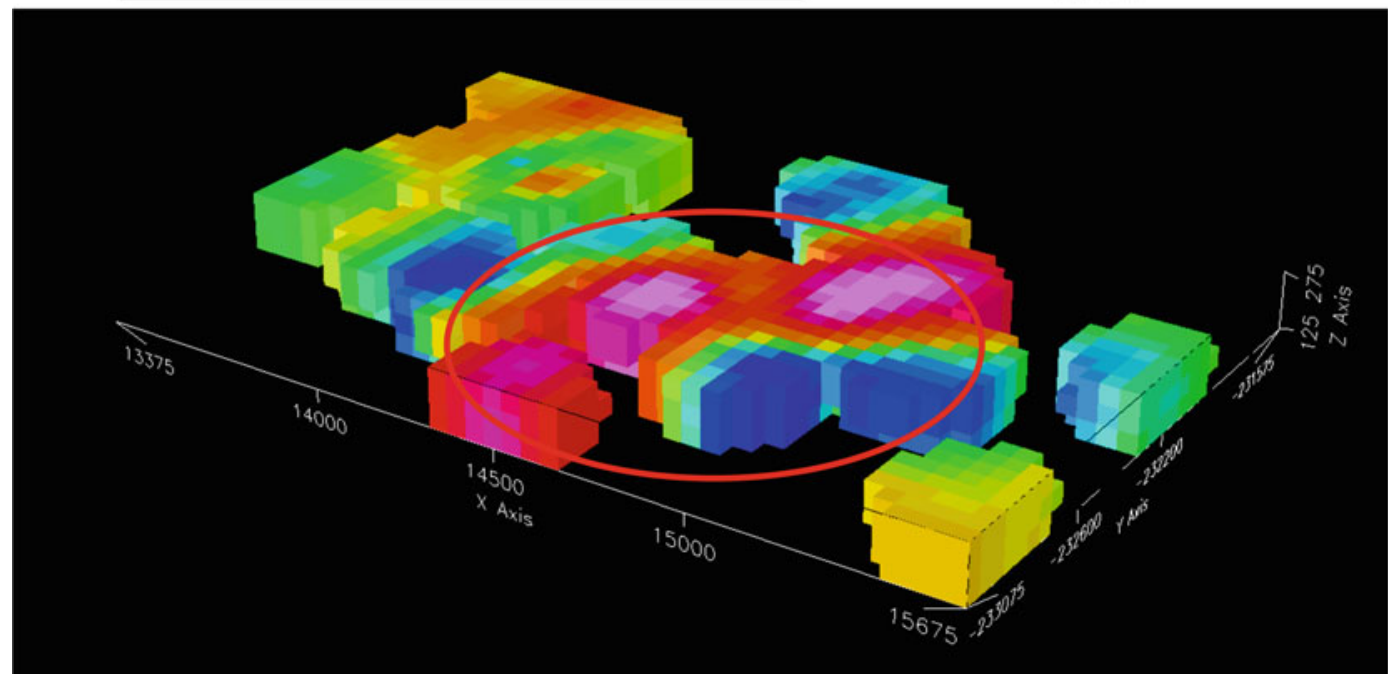

Fig. 11.27 3D Cu (\%) in drill holes from the Neves Corvo mine area

orebodies of Neves Corvo mining site. Therefore, the other anomalies, observed further away in Fig. 11.26 are worth being investigated in the Neves Corvo mine area. Furthermore, it would be relevant to consider if gravity inversion modelling should be applied in the rest of the area where this kind of information is available.

\subsection{Summary and Conclusions}

The use of 3D, 4D and predictive geological modelling for the Neves Corvo $100 \times 25 \mathrm{~km}$ project area enabled to correlate its geological, 
stratigraphical, geochronological, structural, mineral deposit, geophysical, geochemical and other characteristics. Half of the area, the western part, is known to contain the Givetian to Famennian-Strunian Phyllite-Quartzite Group (PQG), overlain, along the three volcanic axes, by the Strunian to Visean Volcanic Sedimentary Complex (VSC), hosting in its lower sequence the Neves Corvo VHMS giant deposit and the Montinho and Algaré small VHMS deposits. Additionally, an inlier of VSC outcrops in Alcoutim, adjacent to the Spanish border in the eastern end of the project area. The remaining area is covered by Visean and Serpukhovian to Moscovian flysch rocks [Mértola and Mira formations of the Baixo Alentejo Flysch Group (BAFG), respectively]. The three volcanic axes that plunge to the SE are known to extend at depth under the BAFG sedimentary rocks in the eastern part of the area, where they were modelled in 3D as well.

A particularly relevant feature of the area is the NW-SE (dipping to NE) Neves Corvo main thrust bringing VSC rocks on top of the Mértola Fm., extremely close to Neves Corvo VHMS ores. This main thrust serves in Neves Corvo mine area as an exploration guide to VHMS ore. The use of six NE-SW very deep 2D reflection seismic profiles carried out by LNEG during this project, between the Neves Corvo mine and the Spanish border, $60 \mathrm{~km}$ to the SE, allowed to extend and 3D-model of the Neves Corvo main thrust throughout all the eastern part of the area.

Late Variscan faults displaced all former geological units and Variscan structures, including thrusts, as shown by the 3D models. They are strike-slip oblique faults, mostly striking NE-SW to ENE-WSW (sinistral) and N-S to NNW-SSE (dextral). In some cases the seismic sections show deep development ( $>5 \mathrm{~km}$ depth) of these fault zones. Also in late Variscan time, small vein-type $\mathrm{Cu}$ (and other metals) deposits and occurrences, abundant in the eastern part of the area, were emplaced along these faults, also used during the Middle Jurassic to locally accommodate intrusions of dolerite dykes, particularly along the prominent NW-SE sinistral Messejana fault in the northwesternmost end of the area.
The 4D model enabled to establish a clear age succession, important for the succeeding mineralization types, namely Strunian VHMS mineralization in VSC lower sequence, Visean Mn mineralization in VSC upper sequence and late Variscan vein-type $\mathrm{Cu}$-sulphide mineralization associated with late Variscan faults. Particularly important was the constraint of the Neves Corvo main thrust to a Serpukhovian to Moscovian age (Fig. 11.23). The 4D model also shows that in Strunian time the lower sequence of the VSC (the sequence hosting VHMS mineralization) may possibly exist at depth (dashed lines in Fig. 11.22) in between the Neves Corvo mine and Alcoutim.

The parameters used for the predictive modelling that took into account (1) the position of Neves Corvo main thrust in the central and eastern areas, (2) the position of VHMS deposits and vein-type $\mathrm{Cu}$ deposits in close proximity to this thrust and to Late Variscan faults in the latter case and (3) the proximity of gravimetric and magnetic anomalies. All point out, in the 2D predictive model, that the vicinity of this thrust between Neves Corvo mine and the Spanish border is an extremely important target for volcanic-hosted massive sulphide deposit exploration. Also relevant for this purpose may be the Alcoutim area, with above-mentioned vein-type $\mathrm{Cu}$ occurrences, and where the Neves Corvo main thrust, which is very deep farther away, is closer to the surface $(\approx 1000 \mathrm{~m}$ deep) due to late Variscan faults. Furthermore, the thrust consists of the characteristic VSC/thin flysch sequence at depth, as in the Neves Corvo mine. The 3D predictive model, exclusively done for the Neves Corvo mine area, pinpoints, both through the 3D-density (from gravity inversion) and the $\% \mathrm{Cu}$ drill hole-based block-diagrams, the known Neves Corvo orebodies, including the newly discovered deposits, but also other possible extensions.

The regional extension of the Neves Corvo model increases significantly the exploration potential of this part of the IPB. The ProMine LNEG/AGC-Lundin Mining team work improved the geological knowledge of the Portuguese IPB sector, showing new possibilities for VHMS deposits discoveries. 
Acknowledgments The authors thank LNEG and Lundin Mining for supporting this study and allowing the publication of its results. Augusto Filipe (LNEG) is thanked for improving and editing several figures.

\section{References}

Barriga, F., Carvalho, D., 1983. Carboniferous volcanogenic sulphide mineralizations in south Portugal (Iberian Pyrite Belt). Memórias dos Serviços Geológicos de Portugal v. 29, pp. 99-113.

Boogaard, M.V., Schermerhorn, L.J.G., 1981. Conodont faunas from Portugal and Southwestern Spain, Part 6A Lower Famennian faunas at Monte Forno da Cal (South Portugal). Scripta Geologica, 63,1-16.

Camacho, A.G., Montesinos, F.G., Vieira, R., 2002. A 3$\mathrm{D}$ gravity inversion tool based on exploration of model possibilities. Computers \& Geosciences, 28, 191-204.

Carbonell, R., Simancas, F., Juhlin, C., Pous, J., PérezEstaún, A., González-Lodeiro, F., Muñoz, G., Heise, W., Ayarza, P., 2004. Geophysical evidence of a mantle derived intrusion in SW Iberia. Geophysical Research Letters 31, L11601,.

Carvalho, D., 1982. New paths to massive sulphide exploration in the Iberian Pyrtite Belt. Comunicações Serviços Geológicos Portugal, 68 (2), 149-162

Carvalho D, Barriga F J A S, Munhá J., 1999. Bimodalsiliciclastic systems - the case of the Iberian Pyrite Belt. In: Barrie, C.T., Hannington, M.D. (eds.), VolcanicAssociated Massive Sulphide Deposits: Processes and Examples in Modern and Ancient Settings, Reviews Economic Geology, 8, 375-408.

Carvalho, J., Sousa, P., Matos, J., Pinto, C., 2011. Ore prospecting in the Iberian Pyrite Belt using seismic and potential-field data. Journal of Geophysics and Engineering 8 (2), 142-153.

Cordsen, A., Galbraith, M., Peirce, J.,2000. Planning Land 3-D Seismic Surveys. SEG Geophysical Development Series No. 9, Tulsa, Oklahoma (OK), USA, $204 \mathrm{p}$

Eaton, David W., 2003. Hardrock Seismic Exploration. SEG Geophysical Development Series No 10, Tulsa, OK, USA, $270 \mathrm{p}$.

Germann, K., Luders V., Banks, D.A., Simon K., Hoefs, J., 2003. Late Hercynian polymetallic vein-type basemetal mineralization in the Iberian Pyrite Belt: fluidinclusion and stable-isotope geochemistry ( $\mathrm{S}-\mathrm{O}-\mathrm{H}-$ Cl). Mineralium Deposita, 38: 953-967.

Hubral, P. (ed.), 1999. Macro model independent seismic reflection imaging. Journal of Applied Geophysics, 42 (3-4) - Special issue on Karlsruhe Workshop on macro model independent seismic reflection imaging.

Kaiser, H. F., 1960. The application of electronic computers to factor analysis. Educational and Psychological Measurement, 20, 141-151.
Kim, J. S., Moon, W. M., Lodha, G., Serzu, M., Soonavvala, N., 1994. Imaging of reflection seismic energy for mapping shallow fracture zones in crystalline rocks, Geophysics, 59, 753-765.

Korn, D., 1997. The Palaeozoic ammonoids of the South Portuguese Zone. Memórias do Instituto Geológico e Mineiro, 33, 131 p..

Leca, X; Ribeiro, A; Oliveira, T.; Brandão Silva, J.; Albouy, P.; Carvalho, P.; Merino, H., 1983. Cadre Géologique des Mineralisations de Neves Corvo, Baixo-Alentejo, Portugal, Litostratigraphie, Paléogéographie et Tectonique": Mémoire du Bureau de Recherches Géologiques et Minières, Orléans, n 121, 79 p.

Leitão, J., 1997. Geology of the Aljustrel massive sulphide deposits, in Barriga, F.J.A.S., Carvalho, D., eds., Geology and VMS deposits of the Iberian Pyrite Belt: Society of Economic Geologists Field Trip Guidebook Series, v. 27, p. 82-97.

Lundin Mining, 2010. Management's discussion and analysis for the year ended December 31, 2010 Lundin Mining Press Release, www.lundinmining.com Lundin Mining, 2012. Third Quarter 2012 Exploration Update press release, http://www.lundinmining.com/s/ ExplorationUpdate.asp?ReportID $=555171$.

Mann, J., Hubral, P., Hocht, G., Jaeger, R., Mueller, T., 1999. Applications of the common-reflection-surface stack:, in 69th Annual International Meeting of the Society of Exploration Geophysicists, 1829-1832.

Mateus, A. Munhá, J., Andráš, P., Matos, J.X., 2006. Geoquímica isotópica do chumbo em mineralizações hidrotermais antimoníferas do Sul de Portugal. VII Congresso Nacional de Geologia. Universidade de Évora, Livro de Resumos, v. 3, p. 1039-1042.

Matos, J.X., Rosa, C., 2001. Diagnóstico Preliminar de Minas Abandonadas - Área Sul. Relatório Interno, Instituto Geológico e Mineiro, 276 pp (in Portuguese).

Matos, J. X., Martins, L. P., Rosa, C., 2003. Parque Mineiro da Cova dos Mouros - IGM contribute for the sustainable development of the mining park. IGME, Cuadernos del Museo Geominero, n 2, 487-494.

Matos, J., Pereira, Z., Rosa, C., Rosa, D. N, Oliveira, J. T., Relvas, J., 2011. A key time frame for VMS deposit exploration in the Iberian Pyrite belt. SGA 2011, $11^{\text {th }}$ Biennial Meeting, Antofagasta, Chile, 790-792.

Munhá J., 1983a. Low grade regional metamorphism in the Iberian Pyrite Belt: Comunicações Serviços Geológicos de Portugal, 69,3-35.

Munhá J., 1983b. Hercynian magmatism in the Iberian Pyrite Belt. In: Sousa M J L, Oliveira JT. (eds.), The Carboniferous of Portugal, Memórias Serviços Geológicos Portugal 29: 39-81.

Munhá, J., 1990. Metamorphic evolution of the South Portuguese/Pulo do Lobo Zone. In: Dallmeyer, R.D., Martinez-Garcia, E. (eds.), Pre-Mesozoic geology of Iberia. Berlin, Springer-Verlag, 363-368.

Oliveira, JT., 1983.The marine Carboniferous of South Portugal: a stratigraphic and sedimentological approach. In: Sousa M J L, Oliveira JT (eds), The 
Carboniferous of Portugal, Memórias Serviços Geológicos Portugal 29, 3-37.

Oliveira, J.T., Wagner-Genthis, C., 1983, The Mértola and Mira formations boundary between Doguedo and Almada do Ouro, marine Carboniferous of South Portugal. In: Lemos de Souda, M.J. (ed.), Contributions to the Carboniferous Geology and Palaeontology of the Iberian Península. Porto, Univ. Porto - Faculdade de Ciências, 1-39.

Oliveira, J. T., Monteiro, J. H., Zbyszewski G., Manuppella, G., Oliveira V., 1984. Carta Geológica de Portugal, 1/200 000, Folha 7 and Notícia Explicativa. Lisboa, Serviços Geológicos de Portugal (in Portuguese).

Oliveira, J.T., Garcia-Alcaide, J., Liñan, E., Truyols, J., 1986. The Famennian of the Iberian Peninsula. An. Soc. Géologique Belgique, 109, 159-174.

Oliveira, J. T., Oliveira, V., Manuppella, G., Zbyszewski G., Monteiro, J. H., 1992. Carta Geológica de Portugal, 1/200 000, Folha 8 and Notícia Explicativa. Lisboa, Serviços Geológicos de Portugal (in Portuguese).

Oliveira, JT, Pacheco, N, Carvalho, P, Ferreira, A., 1997. The Neves Corvo Mine and the Paleozoic Geology of Southwest Portugal. In: F JAS Barriga and D. Carvalho, eds : Geology and VMS Deposits of the Iberian Pyrite belt. SEG Neves Corvo Field Conference, 1997, Field trip \# 1. Guidebook Series Volume 27. Society of Economic Geologists, p. 21-71.

Oliveira, V., Matos, J.X., Bengala, M., Silva, N., Sousa, P. e Torres, L., 1998. Geology and Geophysics as Successful Tools in the Discovery of the Lagoa Salgada Orebody (Sado Tertiary Basin - Iberian Pyrite Belt), Grândola, Portugal. Mineralium Deposita, 33: 170-187.

Oliveira JT, Pereira Z, Carvalho P, Pacheco N, Korn D., 2004. Stratigraphy of the tectonically imbricated lithological succession of the Neves Corvo mine area, IPB, Portugal. Mineralium. Deposita 39, 422-436.

Oliveira JT, Relvas JMRS, Pereira Z, Matos JX, Rosa CJ, Rosa D, Munhá J, Jorge R, Pinto A., 2006. O Complexo vulcano-sedimentar da Faixa Piritosa: estratigrafia, vulcanismo, mineralizações associadas e evolução tectono-estratigráfica no contexto da zona SulPortuguesa: In Dias R, Araújo A, Terrinha P, Kulberg JC (eds) Geologia de Portugal no contexto da Ibéria: VII Cong. Nac. Geologia, Universidade de Évora, Portugal: 207-244.

Oliveira JT, Rosa C, Pereira Z, Rosa D, Matos J, Inverno C, Andersen T., 2013. Geology of the Rosário - Neves Corvo antiform, Iberian Pyrite Belt, Portugal: new insights from physical volcanology, palynostratigraphy and isotope geochronology studies. Mineralium Deposita, 48, 749-766.

Pereira Z, Pacheco N, Oliveira JT., 2003. A case of applied palynology: dating the lithological succession of the Neves-Corvo Mine, Iberian Pyrite Belt, Portugal. In: Wong TE (ed) Proceedings of the XVth International Congress on Carboniferous and Permian Stratigraphy. R. D. Academy Arts and Sciences, Utrecht, The Netherlands, pp 345-354.
Pereira Z, Matos J X, Fernandes P, Oliveira J T, 2008. Palynostratigraphy and systematic palynology of the Devonian and Carboniferous successions of the South Portuguese Zone, Portugal. Memórias Geológicas do INETI, 34, $181 \mathrm{p}$.

Pereira, Z., Matos, J., Fernandes, P., Jorge; R., Oliveira. J. T., 2009. A new Lower Givetian age Miospores of the Phyllite Quartzite Group (S. Francisco da Serra Anticline, Iberian Pyrite Belt, Portugal). In: Abstracts Cimpfaro'09. Fernandes, P., Pereira, Z., Oliveira, J.T., Clayton, C \& Wicander, R. (eds)., pp. 75-78.

Quesada, C., 1998. A reappraisal of the structure of the Spanish segment of the Iberian Pyrite Belt. Mineralium Deposita, 33: 31-44.

Radzevicius, S. J., Pavlis, G. L., 1999. High-frequency reflections in granite? Delineation of the weathering front in granodiorite at Piñon Flat, California, Geophysics, 64, 1828-1835.

Reiser, F. K. M., Rosa, D.R. N., Pinto, Á.M. M., Carvalho, J.R. S., Matos, J'.X., Guimarães, F.M. G., Alves, L.C. and de Oliveira, D. P. S., 2011. Mineralogy and geochemistry of tin- and germaniumbearing copper ore, Barrigão re-mobilized vein deposit, Iberian Pyrite Belt, Portugal, International Geology Review, 53 (10), 1212-1238.

Relvas, J.M.R.S., Barriga, F.J.A.S., Ferreira, A., Noiva, P. C., Pacheco, N., Barriga, G., 2006a. Hydrothermal alteration and mineralization in the Neves-Corvo volcanic-hosted massive sulphide deposit, Portugal: I. Geology, mineralogy, and geochemistry. Economic Geology, 101: 791-804.

Relvas, J.M.R.S., Barriga, F.J.A.S., Longstaffe, F.J., 2006b. Hydrothermal alteration and mineralization in the Neves-Corvo volcanic-hosted massive sulphide deposit, Portugal: II. Oxygen, hydrogen, and carbon isotopes. Economic Geology, 101: 753-790.

Rosa C, McPhie J, Relvas J, Pereira Z, Oliveira T, Pacheco N., 2008. Facies analyses and volcanic setting of the giant Neves Corvo massive sulphide deposit, Iberian Pyrite Belt, Portugal. Mineralium Deposita, 43: 449-466.

Schermerhorn, L.J.G., Zbyszewski, G., Veiga Ferreira, O., 1987. Notícia Explicativa da Folha 42-D (Aljustrel), Carta Geológica de Portugal, escala 1:50,000: Lisboa, Serviços Geológicos de Portugal, 55 p. (in Portuguese).

Silva, J.B., Oliveira, J.T., Ribeiro, A., 1990. South Portuguese Zone. Part VI. Structural outline. In: Dallmeyer, R.D., Martínez García, E. (eds.). Pre-Mesozoic Geology of Iberia. Springer, Berlin, 348-362.

Simancas, J.F., Carbonell, R., González Lodeiro, F., Pérez Estaún, A., Juhlin, C., Ayarza, P., Kashubin, A., Azor, A., Martínez Poyatos, D., Almodóvar, G.R., Pascual, E., R. Sáez, R., Expósito, I., 2003. Crustal structure of the transpressional Variscan orogen of SW Iberia: SW Iberia deep seismic reflection profile (IBERSEIS). Tectonics, 22 (6), TC1062, 1-11-1-19 